\title{
DISTAL MANUAL PHALANGES OF UPPER PLEISTOCENE HOMO FROM ALTAI CAVES
}

Introduction. The paper comprises a comparative morphological study of the distal manual phalanges of the second to fifth rays of fossil inhabitants of the Altai Mountains. Based on previous study, this region is expected to be a contact zone between Denisovans and Neanderthals.

The goal of the study. We tested a hypothesis about the presence in the Pleistocene Altai of hominids of differing origin and, in particular, the existence of distinctive morphological variants among Neanderthal settlers of Altai.

Material and methods. Manual distal phalanges from excavations in caves Denisova, Chagyrskaya and Strashnaya were measured, $X$-ray filmed and scanned before sampling for ancient DNA extraction. Scanning was performed using an X-ray microscope, whose imaging resolution is sufficient to combine traditional radiological methods with non-destructive microscopy.

Results. Our results show high morphological diversity among the Upper Pleistocene population. Three of four studied samples were identified as Neanderthals (Denisova 9, male (?), Chagyrskaya 08 and 56, females) by long, wide and flat diaphysis, and a wide and rounded apical tuft. The phalanx Strashnaya 4 features anatomically modern traits and does not correspond to Neanderthal specimens in proportions or dimensions. It is short with relatively narrow and tall diaphysis. Modern techniques of radiological investigation reveal two different morphological variants present in Altai Neanderthals from Denisova and Chagyrskaya. Phalanges show substantial changes in internal structure. In the distal half of Denisova 9, the space of the medullary canal was fully displaced by osteonised tissue, resembling a variant of the "ivory" epiphyses - in particular distributed among modern humans of African ancestry. Denisova 9 joins with the modern human Strashnaya 4 by high corticalisation at the midshaft (\%CA 92,85 and 82,61correspodingly). Chagyrskaya 08 and 56 are thin-walled (\%CA 58,77 and 30,88). Non-destructive radiological microscopy revealed further differences among the samples: greater and denser bone mass in the case of Strashnaya 4, low mineralised compact of all Neanderthals.

Conclusion. The data may indicate the presence among Altai groups of Neanderthals who differed by origin, and/or chronologically. Patterns of Denisova 9 can be discussed in the context of his hybrid ancestry.

Keywords: paleoanthropology; osteometry; Denisova, Chagyrskaya, Strashnaya caves; Neanderthals; anatomically modern humans; radiology; microscopy

\section{Introduction}

Findings from research in southern Siberia (Altai, Russia) currently play a pivotal role in attempts to reconstruct some important patterns of human evolution. Favourable natural and climatic conditions in the local caves have led to exceptional preservation of ancient DNA in fragmentary human remains [Meyer et al., 2012; Prüfer et al., 2014]. Palaeogenetic research involving mtDNA from the phalanx of a child (Denisova 3) found in stratum 11.2 of the Denisova Cave resulted in the discovery of previously unknown extinct fossil hominins [Krause et al., 2010]. This lineage, the
Denisovans, branched off before the Neanderthal lineage and proceeded to develop independently over a broad coverage of Asia [Reich et al., 2010]. Hybridisation of Denisovans and Homo sapiens - as evidenced in modern populations in Southeast Asia, Australia and Oceania has become a topic of great research interest [Reich et al., 2011]. Till now Denisovans, who had been identified by genetic analysis and solely in the Denisova Cave, had been represented by the remains of four individuals; as well by a part of a child's distal hand phalanx Denisova 3; by two adult molars Denisova 4, Denisova 8; and by a lower second deciduous molar Denisova 2 [Douka et al., 2019]. The latter individual - a girl of 10-12 years -
АНТРОПОЛОГИЯ № 2/2020: 5-25

Anthropology, 2020, no. 2, pp. 5-25
Вестник Московского университета. Серия ХХIII Moscow University Anthropology Bulletin 
was one of the chronologically oldest humans discovered at the Denisova Cave. Based on results from relative mtDNA dating, she had lived 54.2-99.4 thousand years earlier than the younger girl Denisova 3.

However, Denisovans were not the only inhabitants of the Pleistocene Altai. Archaeological data [Derevianko, Markin, 1992; Derevianko et al., 2013], palaeogenetic analyses [Krause et al., 2007], and palaeoanthropological studies [Buzhilova, 2013; Mednikova, 2011a, 2013a; Viola et al., 2012, 2018] regarding the Okladnikov and Chagyrskaya caves jointly point to the presence of Neanderthal migrants, who created a local Sibiryachikha variety of the Mousterian industry [Derevianko et al., 2013].

In turn, this question touches upon the concurrent settlement of southern Siberia by diverse fossil humans over the period prior to $50 \mathrm{ka}$. At that time Altai was a contact zone where Denisovans - long present in the region - adjoined Neanderthal migrants [Prüfer et al., 2014]. The distance between the Denisova Cave - a refuge for the Denisovans - and the Chagyrskaya and Okladnikov caves, where Neanderthals lived, was in the order of only $100 \mathrm{~km}$ - not a long distance for the movements of Palaeolithic hunters. Given these circumstances, hybridisation between Denisovans and Neanderthals living in such close proximity seemed probable.

Moreover, Neanderthal remains were found in the Denisova Cave itself.

An adult proximal pedal phalanx of the fourth or fifth ray excavated in stratum 11.4 was broad relative to its height - even broader and more robust than the phalanges of Neanderthals or early modern humans [Mednikova, 2011b].

Confirmation of its attribution was provided by highcoverage sequencing of representative Neanderthal DNA. Analysis of relationships and the history of available archaic and 25 modern genomes showed genetic flows between Neanderthals, Denisovans and modern humans. Gene flow to Denisovans was shown to have come from a previously unknown genetically archaic group [Prüfer et al., 2014].

Morphologically the pedal phalanx of this Altai Neanderthal female Denisova 5 was closest to the Shanidar-4 Neanderthal, and the anatomically modern human Tianyuan 1 [Mednikova, 2011b]. These results are broadly consistent with later genetic analysis, which found that a population that diverged early on from modern humans in Africa contributed genetically to the ancestors of Altai Neanderthals roughly 100,000 years ago [Kuhlwilm et al., 2016; Rogers et al., 2020].

The Denisova Cave seems to have been a constant home for both Altai Neanderthals and Denisovans. Anew individual, Denisova 11, was identified by collagen fingerprinting and mitochondrial DNA analysis in morphologically non-diagnostic bone [Brown et al., 2016].
She had a Denisovan father and a Neanderthal mother, who came from a population more closely related to Neanderthals lived later in Europe than to an earlier Neanderthal Denisova 5, suggesting that migrations of Neanderthals between eastern and western Eurasia occurred sometime after 120,000 years ago [Slon et al., 2018].

A growing number of Neanderthal remains from recent excavations allow the suggestion that inhabitants of all three caves (Okladnikov, Denisova and Chagyrskaya), seemed to be morphologically diverse. So, if compared with Neanderthals from Denisova or Okladnikov, humans from Chagyrskaya were "lighter-built", especially concerning the inner robusticity of their tubular bones. That could mean different waves of Neanderthal migration or their genetic contacts with another humans [Mednikova, 2015]. Luminescence chronology for the Denisova and Chagyrskaya Caves might uncover time differences between these Neanderthal palaeopopulations [Jacobs et al., 2016].

A manual distal phalanx (Denisova 9) from an adult Neanderthal individual has been found in stratum 12 of the Denisova Cave [Mednikova, 2013b].

Additional distal manual phalanges were found in 2011, 2012 and 2015 in Pleistocene layers in the Chagyrskaya and Strashnaya caves. All three caves are in the north-western, low-mountain portion of Altai. The Denisova Cave (N 51 ${ }^{\circ} 23^{\prime} 48^{\prime \prime}, \mathrm{E} 84^{\circ} 40^{\prime} 35^{\prime \prime}$ ) is located in a valley along the upper Anui river at an absolute elevation of $690 \mathrm{~m}$. The Chagyrskaya Cave (N 51 ${ }^{\circ} 26^{\prime} 34^{\prime \prime}$,

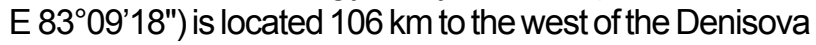
Cave, in the valley of the lower Charysh river at an elevation of $362 \mathrm{~m}$ above sea level. The Strashnaya Cave (N 51 ${ }^{\circ} 10^{\prime 2} 26^{\prime \prime}, \mathrm{E} 83^{\circ} 01^{\prime} 42^{\prime \prime}$ ) is $120 \mathrm{~km}$ to the south-west of the Denisova Cave, in a valley along the midcourse of the Inya river (right tributary of the Charysh river) at an absolute elevation of $515 \mathrm{~m}$.

Modern radiological techniques, as well microtomography and X-ray microscopy, allow the investigation of even extremely fragmentary material in non-destructive ways. Such methods have proven particularly useful in caves in the Altai region - where Pleistocene deposits have yielded small isolated specimens, primarily manual or pedal phalanges [Mednikova, 2011b, 2013b], as well as teeth [Buzhilova, 2013]. Histological study of compact bone tissue can differentiate between species [Martiniakova et al., 2007; Crescimanno, Stout, 2012]. It was proposed for identification of individuals in mixed skeletons [Stout, Gehlert, 1979], which hypothetically can be found in the layers of Altai Caves.

In the absence of larger long bones, distal manual phalanges can serve as a source of valuable morphological information. The goal of this article is to describe morphological variety among Altai fossil 
Table 1. Technical parameters of scanning of samples with VersaXRM-500 Таблица 1. Технические параметры сканирования образцов с помощью VersaXRM-500

\begin{tabular}{|c|c|c|c|c|}
\hline \multirow[t]{2}{*}{ Source } & $\begin{array}{l}\text { Denisova-9 } \\
\text { (2 samples) }\end{array}$ & $\begin{array}{c}\text { Chagyrskaya } 08 \text { and } 56 \\
(2 \text { samples from } 2 \text { individuals) }\end{array}$ & $\begin{array}{c}\text { Strashnaya } 4 \\
(1 \text { sample }) \\
\end{array}$ & \multirow[t]{2}{*}{ Units } \\
\hline & \multicolumn{3}{|c|}{ Point, 1 um, W full-spectrum } & \\
\hline Spectral filter & NO & LE\#1* & LE\#2* & $\begin{array}{c}\text { *From Xradia } \\
\text { Standard Filter Kit }\end{array}$ \\
\hline High Voltage & 80 & 50 & 50 & $\mathrm{kV}$ \\
\hline Current & 87,5 & 80 & 80 & $\mathrm{uA}$ \\
\hline $\begin{array}{c}\text { Source-sample } \\
\text { distance }\end{array}$ & 25 & 25 & 33 & $\mathrm{Mm}$ \\
\hline $\begin{array}{l}\text { Sample-detector } \\
\text { distance }\end{array}$ & 96 & 260 & 23 & $\mathrm{Mm}$ \\
\hline Optical magnification & $0.4 \mathrm{X}$ & $0.4 \mathrm{X}$ & $4 X$ & \\
\hline Projections number & 1600 & 1440 & 1800 & Pcs \\
\hline Angle range & full 360 & full 360 & full 360 & Degrees \\
\hline Exposure time & 0.5 & 6 & 3 & $\mathrm{Sec}$ \\
\hline Camera size & 4 & 4 & 4 & Megapixels \\
\hline Camera binning & 2 & 2 & 2 & \\
\hline Image size & $1024 \times 1024$ & $1024 \times 1024$ & $1024 \times 1024$ & Pixels \\
\hline Voxel size & 14,06 & 5,97 & 4,01 & $\mathrm{Um}$ \\
\hline
\end{tabular}

specimens, by comparing the four distal phalanges of rays 2-5 from the Denisova, Chagyrskaya and Strashnaya Caves. We are going to test hypothesis about the presence in Pleistocene Altai of humans of different origin and to follow distinctive morphological variants among Neanderthal settlers of Altai.

The distal manual phalanges were imaged using non-destructive radiological methods. Micro-focus X-ray investigation had previously identified unusual internal structure of the distal phalanx of the third ray from stratum 12 of the Denisova Cave [Mednikova, 2013b]. Here we provide the results of the microtomography and X-ray microscopy. These studies of distal manual phalanges from the Chagyrskaya and Strashnaya caves have not been published previously. Therefore the current work includes identification, comparative analysis of the external and internal structures, estimation of the biological age of the specimens, and analysis of any pathologies found.

\section{Methods}

External measurements were performed using a GMC-190 digital vernier caliper (accuracy, $0.01 \mathrm{~mm}$, or 0.0053 ). The programme included 11 standard measurements and 2 indices: articular length, midshaft height, midshaft breadth, midshaft circumference, proximal maximal height, proximal maximal breadth, proximal articular height, proximal articular breadth, distal height, distal breadth, tuberosity height, index of section at diaphyseal midshaft (height:breadth,\%), index of robusticity (breadth:articular length,\%) [Trinkaus, 1983; Pearson, 1997, see comments to Table 3].

Phalanges from Chagyrskaya and Strashnaya were measured, X-ray filmed and scanned before sampling for ancient DNA extraction. The phalanx from Denisova was preliminary measured, filmed and CTscanned by the Discovery HD 750 tomograph (USA) before sampling [Mednikova, 2013b]. Then Denisova 9 was studied with new equipment.

Scanning was performed using VersaXRM-500 apparatus from Xradia Inc. at the "Systems of Microscopy and Analysis" Lab, Moscow. VersaXRM is an X-ray microscope (XRM), unlike ordinary MicroCT, whose imaging resolution is sufficient to combine traditional radiological methods with non-destructive microscopy. Unlike the traditional projection-based Micro CT, which depends exclusively on geo mag limits at highest resolution to $<1 \mathrm{~mm}$ samples, and has some difficulties in discerning low-contrast samples, the XRM has small detector pixels ( 2 stage magnification) to maintain a high resolution for samples from $<1 \mathrm{~mm}$ and to as large as $50 \mathrm{~mm}$. The phase-enhanced contrast detector enables excellent imaging of low contrast samples.

The equipment had already demonstrated its effectiveness in a pilot histology study of the phalanx of 
a Denisovan girl (individual Denisova 3) from stratum 11.2 of the Denisova Cave [Mednikova et al., 2013]. The technical information from the scanning in the current study is presented in Table 1.

Xradia software was used to create 3D models and virtual cross-sections, and also to measure osteons. Femur, humerus and rib have been traditional objects for the application of histomorphometric techniques [Kerley, 1965; Frost, 1987; Stout, Teitelbaum, 1976; Stout, Stanley, 1991; Stout, Paine, 1992; Uytterschaut, 1985; Iwaniec et al., 1998], whereas manual distal phalanges have not been studied in this way so frequently. Yet it has been pointed out that there are variations in histomorphology and histomorphometry within and between human bones [Robling, Stout, 1999; Cressimano, Stout, 2012; Qui et el, 2003; Mulhern, 2000; Pirock et al,; 2006]. For this reason, in the absence of representative data concerning the histology of distal human phalanges we have to consider the common microstructural picture and the reduced number of features. Maximal and minimal diameters of the secondary osteons were measured, basing on presence of the cement line, as well maximal and minimal diameters of Haversian canals. Among 4 types of secondary osteons [Robling, Stout, 1999] - common, embedded, double zonal and drifting those - we measured osteons of two first types and did so in the middle portion of the dorsal compact.

Osteon measurements for the Neanderthal distal phalanx of Denisova 9 were taken in two remainders of the bone which were not used for extraction of ancient DNA: at the level of the transition from the distal tuberosity to the diaphysis and in the dorsal compact at the middle diaphysis.

For the other samples, comparison was made of cross-sections of the dorsal compact bone at midshaft. The percentage of the cortical area (\%CA) was estimated at midshaft level, and calculated as a ratio of cortical area to total area of the diaphyseal section.

In addition, digital micro-focus radiography of all objects with magnification was performed at the Institute of Archaeology of the Russian Academy of Sciences using a PRDU-02 X-ray machine, along with an HD-CD 35 NDT/CR 35 NCD scanner for optical reading.

A listing of the 58 fossil distal phalanges of the second-fourth digits used for comparative morphological analysis is presented in Table 2. The comparative data of modern humans were also taken [Russians - BonchOsmolovsky, 1941; Sykh, Australian - McCown, Keith, 1939]. A comparative sample of adult modern natives of known age and gender from the Altai highlands was used. About 90 percent of this group were involved in physical labour. X-ray films of the left hands of living people were collected by an expedition from Moscow University under the supervision of Prof. T.Alexeeva in 1976-1986. We took measurements of the row III on radiographs. The articular length of the distal phalan $x$ was the maximal distance between the central part of the articular surface of the base and the head. The breadth of the phalanx was measured at midshaft level. The breadth of the proximal epiphysis was the maximal distance between the ulnar and radial margins. The breadth of the head was a maximal distance between the ulnar and radial margins perpendicularly to vertical axis.

PCA from the Statistica 10 programme (Multivariate Exploratory techniques, Principal component/Classification analysis) was provided for 37 fossil samples and based on 5 measurements - articular length; distal breadth; proximal maximal breadth; midshaft breadth; and midshaft height.

\section{Results}

\section{Identification}

The Chagyrskaya Cave (archaeological specimen 2-11or Chagyrskaya-08). Distal phalanx from stratum $6 b$, horizon 2. Intact small long human bone, a distal manual phalanx, found in 2011 (Fig. 1, Table 3). The diaphysis shows anteroposterior flatness; the dorsal surface is smooth and rounded; the palmar surface is flat and more contoured. The bone ends with a distal tuberosity typical of distal phalanges.

By modern criteria of epiphyseal fusion, the bone belongs to an individual over 16 years old (if male) or over 13.5 years old (if female) [Schaefer, Black, Scheuer, 2009]. No external signs of bone degeneration are present. Therefore the phalanx most likely belonged to a young adult or adult individual. Genetically, female sex was determined (Viviane Slon, pers. comm.).

Human distal phalanges of the second - fourth rays cannot be distinguished from one another on the basis of shape alone. But phalanges of the third and fourth digits do tend to be absolutely longer than those of the second and fifth digits [Patel, Maiolino, 2016].

A micro-focus $X$-ray of the distal portion shows up to three reabsorbed Harris lines (indicators of growth disruptions during childhood), which are visible in the lateral projection (Fig. 1e).

The Chagyrskaya Cave (archaeological specimen 16-2-12 or Chagyrskaya 56). Distal phalanx of second ray of the right hand from stratum $6 b$, horizon 3 . This distal phalanx, found in 2012, belongs to either the second or, less likely, fifth ray (Fig.2). Its length is consistent with either interpretation (Table 3). The sharpness of the distal edge - which is associated with second digit [Bonch-Osmolovski, 1941] - makes the 
Table 2. List of comparative fossil materials. Distal phalanges of the second-fourth digits Таблица 2. Перечень сравнительных ископаемых материалов. Дистальные фаланги 2-4 лучей

\begin{tabular}{|c|c|c|c|}
\hline $\begin{array}{c}\text { Distal phalanx } \\
\text { (Ray number and side } \\
\text { indicated in parentheses) }\end{array}$ & $\begin{array}{c}\text { Sample } \\
\text { № }\end{array}$ & Attribution & Source \\
\hline Tianyuan 1 (ray?) & 1 & Early modern human & Shang, Trinkaus, 2010 \\
\hline Kostenki 14 (2, right) & 2 & Early modern human & Mednikova et al., 2016 \\
\hline Kostenki 14 (3, right) & 3 & Early modern human & Mednikova et al., 2016 \\
\hline Kostenki 14 (4, right) & 4 & Early modern human & Mednikova et al., 2016 \\
\hline Sunghir1 $(2$, right $)$ & 5 & Early modern human & Mednikova, 2012; Trinkaus et al., 2014 \\
\hline Sunghir1 $(3$, right $)$ & 6 & Early modern human & Mednikova, 2012; Trinkaus et al., 2014 \\
\hline Sunghir1 (4, right) & 7 & Early modern human & Mednikova, 2012; Trinkaus et al., 2014 \\
\hline DV 3 (2/3, right) & 8 & Early modern human & Sladek et al., 2000 \\
\hline DV 3 (2/3, right $)$ & 9 & Early modern human & Sladek et al., 2000 \\
\hline DV3 $(4$, right $)$ & 10 & Early modern human & Sladek et al., 2000 \\
\hline DV 13 (3/4, undet.) & 11 & Early modern human & Sladek et al., 2000 \\
\hline DV $13(3 / 4$, undet. $)$ & 12 & Early modern human & Sladek et al., 2000 \\
\hline DV 15 (2-4, right?) & 13 & Early modern human & Sladek et al., 2000 \\
\hline DV $16(2 / 3$, undet. $)$ & 14 & Early modern human & Sladek et al., 2000 \\
\hline DV $16(2 / 3$, undet. $)$ & 15 & Early modern human & Sladek et al., 2000 \\
\hline DV $16(2 / 3$, undet. $)$ & 16 & Early modern human & Sladek et al., 2000 \\
\hline DV 16 (4, undet. $)$ & 17 & Early modern human & Sladek et al., 2000 \\
\hline Caviglione & 18 & Early modern human & Courtesy E.Trinkaus \\
\hline Ohalo 2 & 19 & Early modern human & $\begin{array}{c}\text { Karasik et al., 1998; E.Trinkaus, } \\
\text { pers.comm. }\end{array}$ \\
\hline Pataud 227 (3, right) & 20 & Early modern human & Own measurements \\
\hline Pataud 227 (4, right) & 21 & Early modern human & Own measurements \\
\hline Pataud 230 & 22 & Early modern human & E.Trinkaus, pers.comm. \\
\hline Barma Grande 2 & 23 & Early modern human & E.Trinkaus, pers.comm. \\
\hline AreneCandide-IP & 24 & Early modern human & E.Trinkaus, pers.comm. \\
\hline Skhul 4 (3, right $)$ & 25 & Early modern human & McCown, Keith, 1939 \\
\hline Qafzeh 5 & 26 & Early modern human & E.Trinkaus, pers.comm. \\
\hline Qafzeh 7 & 27 & Early modern human & E.Trinkaus, pers.comm. \\
\hline Qafzeh 8 & 28 & Early modern human & E.Trinkaus, pers.comm. \\
\hline Qafzeh 9 & 29 & Early modern human & E.Trinkaus, pers.comm. \\
\hline Shanidar 3 (3?, undet.) & 30 & Neanderthal & Trinkaus, 1983 \\
\hline Shanidar 4 (3?, undet.) & 31 & Neanderthal & Trinkaus, 1983 \\
\hline Shanidar 4 (4?, undet.) & 32 & Neanderthal & Trinkaus, 1983 \\
\hline Shanidar 5 (2?, right) & 33 & Neanderthal & Trinkaus, 1983 \\
\hline Shanidar 5 (3?, right) & 34 & Neanderthal & Trinkaus, 1983 \\
\hline Shanidar $6(2 ?$, left $)$ & 35 & Neanderthal & Trinkaus, 1983 \\
\hline
\end{tabular}


Table 2 continued

Продолжение таблицы 2

\begin{tabular}{|c|c|c|c|}
\hline $\begin{array}{c}\text { Distal phalanx } \\
\text { (Ray number and side } \\
\text { indicated in parentheses) }\end{array}$ & $\begin{array}{c}\text { Sample } \\
\text { № }\end{array}$ & Attribution & Source \\
\hline Amud 1 & 36 & Neanderthal & Trinkaus, 1983 \\
\hline Kebara 2 & 37 & Neanderthal & Karasik et al., 1989 \\
\hline Kiik-Koba 1 (3, right) & 38 & Neanderthal & Bonch-Osmolovsky, 1941 \\
\hline Krapina 206.2 (2 ray) & 39 & Neanderthal & Musgrave, 1977; Radovcic et al., 1988 \\
\hline Krapina 206.3 (3 ray) & 40 & Neanderthal & Musgrave, 1977; Radovcic et al., 1988 \\
\hline Krapina 206.4 (3 ray) & 41 & Neanderthal & Musgrave, 1977; Radovcic et al., 1988 \\
\hline Krapina 206.5 (5 ray) & 42 & Neanderthal & Musgrave, 1977; Radovcic et al., 1988 \\
\hline Krapina 206.6 (3 ray) & 43 & Neanderthal & Musgrave, 1977; Radovcic et al., 1988 \\
\hline Krapina 206.7 (4 ray) & 44 & Neanderthal & Musgrave, 1977; Radovcic et al., 1988 \\
\hline Krapina 206.8 (2/4) & 45 & Neanderthal & Musgrave, 1977; Radovcic et al., 1988 \\
\hline Krapina 206.8 (2/4) & 46 & Neanderthal & Musgrave, 1977; Radovcic et al., 1988 \\
\hline Krapina 206.9 (2/4) & 47 & Neanderthal & Musgrave, 1977; Radovcic et al., 1988 \\
\hline Krapina 206.10 (2/4) & 48 & Neanderthal & Musgrave, 1977; Radovcic et al., 1988 \\
\hline Krapina 206.11 (4) & 49 & Neanderthal & Musgrave, 1977; Radovcic et al., 1988 \\
\hline Regourdou & 50 & Neanderthal & E.Trinkaus, pers.comm. \\
\hline Ferrassie 1 (2, left) & 51 & Neanderthal & Own measurements \\
\hline Ferrassie 1 (3, left) & 52 & Neanderthal & Own measurements \\
\hline Ferrassie 1 (4, left) & 53 & Neanderthal & Own measurements \\
\hline Ferrassie 2 (3, left) & 54 & Neanderthal & Own measurements \\
\hline StCesaire & 55 & Neanderthal & E.Trinkaus, pers. comm. \\
\hline Palomas 28 (2/4) & 56 & Neanderthal & E.Trinkaus, pers. comm. \\
\hline Palomas 96 (2/4) & 57 & Neanderthal & E.Trinkaus, pers.comm. \\
\hline Tabun 1 (3, left) & 58 & Neanderthal & McCown, Keith, 1939 \\
\hline & & \\
\hline
\end{tabular}

first interpretation more likely. Found together established middle phalanx supports belonging to ray II. Based on common size and in comparison with Chagyrskaya 08 this phalanx also belonged to a female of a similar age.

Strashnaya 4. Distal phalanx of fifth(?) ray of the right hand from stratum $3_{1}$, horizon 2 of Strashnaya Cave. Found in 2015, this phalanx is the most consistent in size with the fifth ray in comparison to finds from other Altai caves (Fig. 3, Table 3). The phalanx is symmetrical in shape but, on the dorsal surface, shows deeper curvature on the right side. From the palmar view, the line connecting the medial and lateral edges of the proximal articular surface is slightly raised in the distal direction on the right. These signs are indicative of the bone being the ungual phalanx of the fifth digit of the right hand [Christensen, 2009]. Palaeogenetic analysis identified the female sex of this individual (Viviane Slon, pers. comm.).The absence of fusion features as well involutive changes shows she was older than 13,5 years, a rather young adult or adult [Schaefer, Black, Scheuer, 2009].

Denisova 9 (Fig.4, Table 3). The dimensions of the Denisova phalanx earlier suggested that it might belong to digits II-IV. It was a part of the left (?) hand of an adult individual (probably a male) - likely a third or fourth phalanx [Mednikova, 2013b].

\section{Macromorphology}

In its longitudinal dimensions, breadth of the distal tuberosity, and degree of flatness, the phalanx Denisova 9's morphology corresponds to a Neanderthal, demonstrating strong latitudinal hypertrophy of the diaphysis [Mednikova, 2013b]. 
Table 3. Morphological patterns of manual distal phalanges from Altai caves Таблица 3. Морфологические особенности дистальных фаланг кисти из алтайских пещер

\begin{tabular}{|l|c|c|c|c|}
\hline \multicolumn{1}{|c|}{ Trait } & Denisova 9 & Chagyrskaya-08 & Chagyrskaya-56 & Strashnaya 4 \\
\hline Articular length, mm & 19,10 & 18,23 & 17,52 & 16,50 \\
\hline Midshaft height, mm & 4,46 & 4,71 & 3,95 & 3,91 \\
\hline Midshaft breadth, mm & 8,48 & 6,81 & 7,31 & 4,98 \\
\hline Midshaft circumference, mm & 24 & 21 & 21 & 16 \\
\hline Proximal maximal height, mm & 7,40 & 6,88 & 6,78 & 6,47 \\
\hline Proximal maximal breadth, mm & - & 11,46 & 11,82 & 9,26 \\
\hline Proximal articular height, mm & - & 4,88 & 6,35 & 5,72 \\
\hline Proximal articular breath, mm & - & 10,09 & 9,98 & 8,19 \\
\hline Distal height, mm & 3,72 & 3,64 & 4,18 & 3,19 \\
\hline Distal breath, mm & 11,34 & 9,44 & 9,46 & 6,48 \\
\hline Height of tuberosity (according to Pearson) & 7,97 & 7,75 & 7,48 & 7,79 \\
\hline $\begin{array}{l}\text { Index of cross-section at midshaft level } \\
\text { (height:breath, \%) }\end{array}$ & 52,59 & 69,16 & 54,04 & 78,51 \\
\hline $\begin{array}{l}\text { Index of robusticity } \\
\text { (breadth:articular length, \%) }\end{array}$ & 44,4 & 37,35 & 41,72 & 30,18 \\
\hline
\end{tabular}

Notes: 1. Length from deepest point on the middle of the proximal facet to the most distal point of the head. 2. Breadth on the primary carpal articular facet.

Примечания: 1. Длина от самой глубокой точки в середине проксимальной фасетки до самой дистальной точки головки. 2. Ширина сочленовной фасетки

By ratio between the articular length and distal breadth among modern and fossil humans $(n=120)$ Denisova 9 is close to large Krapina phalanges (Fig.5). Chagyrskaya 08 falls between Ferrassie 2 left third phalanx and sample Palomas 28 . The smaller bone Chagyrskaya 56 in this respect is similar to the third right phalanx of the Upper Palaeolithic male Sunghir 1 (Fig. 5). Strashnaya phalanx, being included in the comparison with phalanges of the second-fourth rays, shows similarity with two early modern humans, Tianyuan 1 and Skhul IV. It should be stressed, although the ranges of variation for Upper Palaeolithic $H$. sapiens partially overlap with Neanderthals, they are better differentiated than modern inhabitants of Siberia, with some individuals demonstrating the "Pleistocene" widening of the apical tuft.

The principal component analysis based on 5 features, included articular length, distal and basal breadths, diaphyseal width and height and described position of 37 fossil humans (Fig.6). Denisova 9, Chagyrskaya 08 and 56 join in one quarter of the graph together with Kiik-Koba 1, Shanidar 3 and 4, Ferrassie 2 , and with two early modern humans Skhul IV and Sunghir 1. Strashnaya 4 is separated with the Upper Palaeolithic modern humans. The closest by form and size to her phalanx seem to be the right bones of the digits III-IV of the Abri Pataud 227 female. This means, our first impression about belonging of Strashnaya to the fifth digit should be accepted cautiously.

Among the distal phalanges of the Altai hominins, this phalanx is the most gracile, short, with a narrow shaft and narrow proximal epiphysis, but it is also the tallest in relative terms. Its distal tuberosity (if considering the small lengthwise dimensions of the bone) is wide and the base shows hypertrophy, especially in its height. But compared to the phalanges from the second and third rays from females Chagyrskaya 08 and 56 and particularly Denisova 9, the Strashnaya 4 has the narrowest distal tuberosity (Table 3).

In comparison to the Neanderthal phalanges of the fifth digits (Table 4), the specimen from Strashnaya Cave is short - similar to the most miniature Upper Palaeolithic $H$. sapiens of Europe - but the circumference of the shaft and diaphyseal breadth at midshaft are larger, similar to Neanderthals. Its diaphysis is high, like in the fifth phalanges of anatomically modern humans Omo1 and Sunghir 1. In terms of breadth at midshaft, the phalanx from Strashnaya Cave is closer to Neanderthal than $H$. sapiens bones, but with respect to the narrow articular breadth of the base, is closer to Cro-Magnon than Neanderthal phalanges. The breadth of tuberosity is lesser than in Neanderthals, but greater than in both the earliest (Kostenki 14) and latest (Abri Pataud) Upper Palaeolithic H. sapiens in Europe (Fig. 7). Thus the phalanx from Strashnaya Cave shows a tendency towards large breadth of the distal tuberosity, which is most pronounced in the Neanderthal phalanx Denisova 9 [Mednikova, 2013b]. Yet by contrast with Denisova 9, the ungual phalanx from Strashnaya Cave is tall, demonstrating a structure consistent with modern anatomy. 


\section{$1 \mathrm{~cm}$}

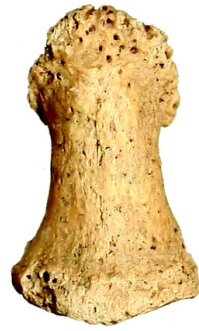

a

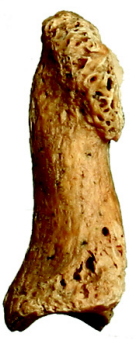

b

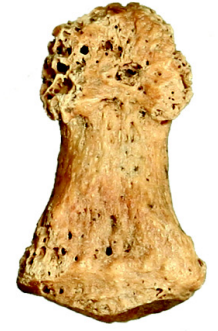

C

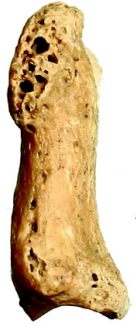

d

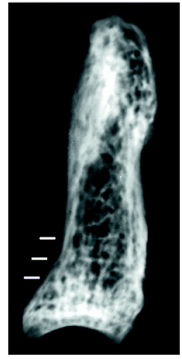

e

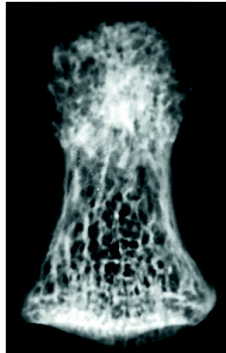

f

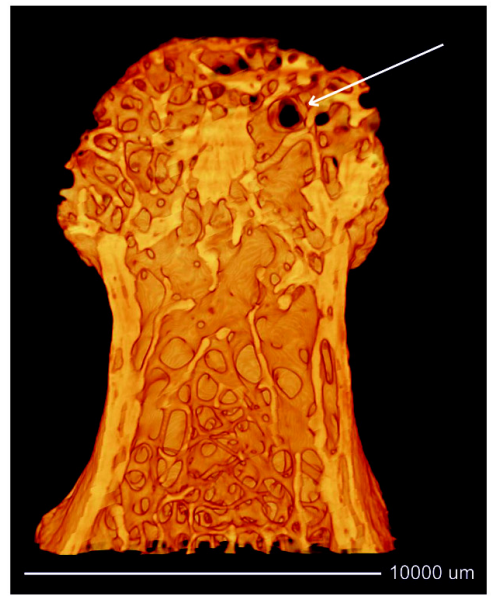

g

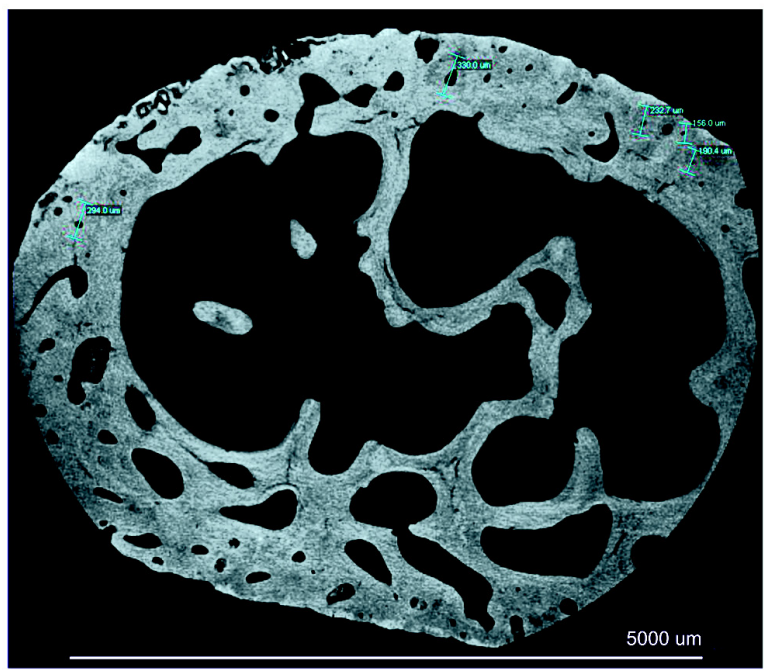

e

Figure 1. Distal manual phalanx Chagyrskaya 08 (2-11): a. dorsal view, b. lateral view, c. palmar view, d. lateral view, e. lateral view by the micro-focus X-ray, f. anterior view by the micro-focus X-ray, g. 3D reconstruction and virtual vertical cross-section in the area of the distal tuberosity, e. virtual cross-section with osteon measurements from the dorsal compact at midshaft (top of the figure)

Рисунок 1. Дистальная фаланга кисти Чагырская 08 (2-11): а. дорзальная поверхность; b. вид сбоку; c. ладонная поверхность; d. вид сбоку; е. боковая проекция на микрофокусной рентгенограмме; f. передняя проекция на микрофокусной рентгенограмме; g. Трехмерная реконструкция и вертикальный виртуальный

срез в области дистальной бугристости, е. Виртуальное сечение с измерениями остеонов дорзальной компакты на уровне середины (верх рисунка) 


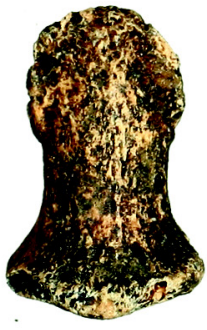

a

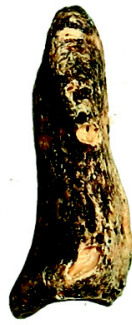

b

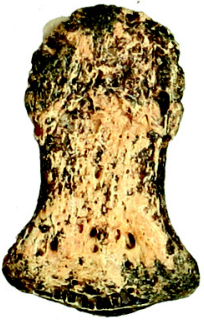

C

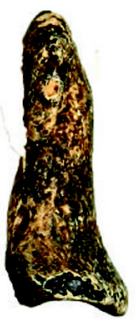

d

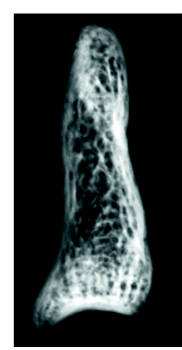

e

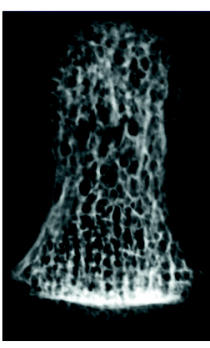

f

g

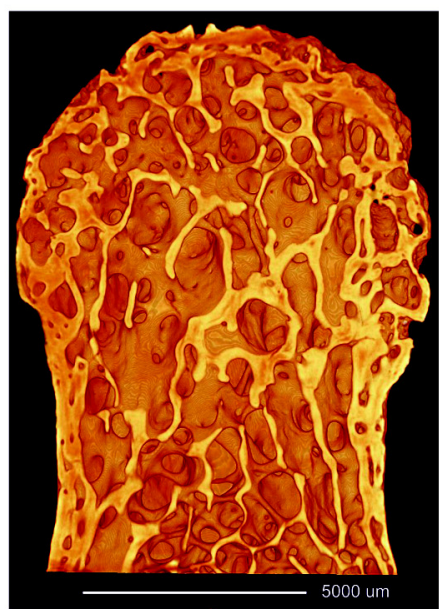

h
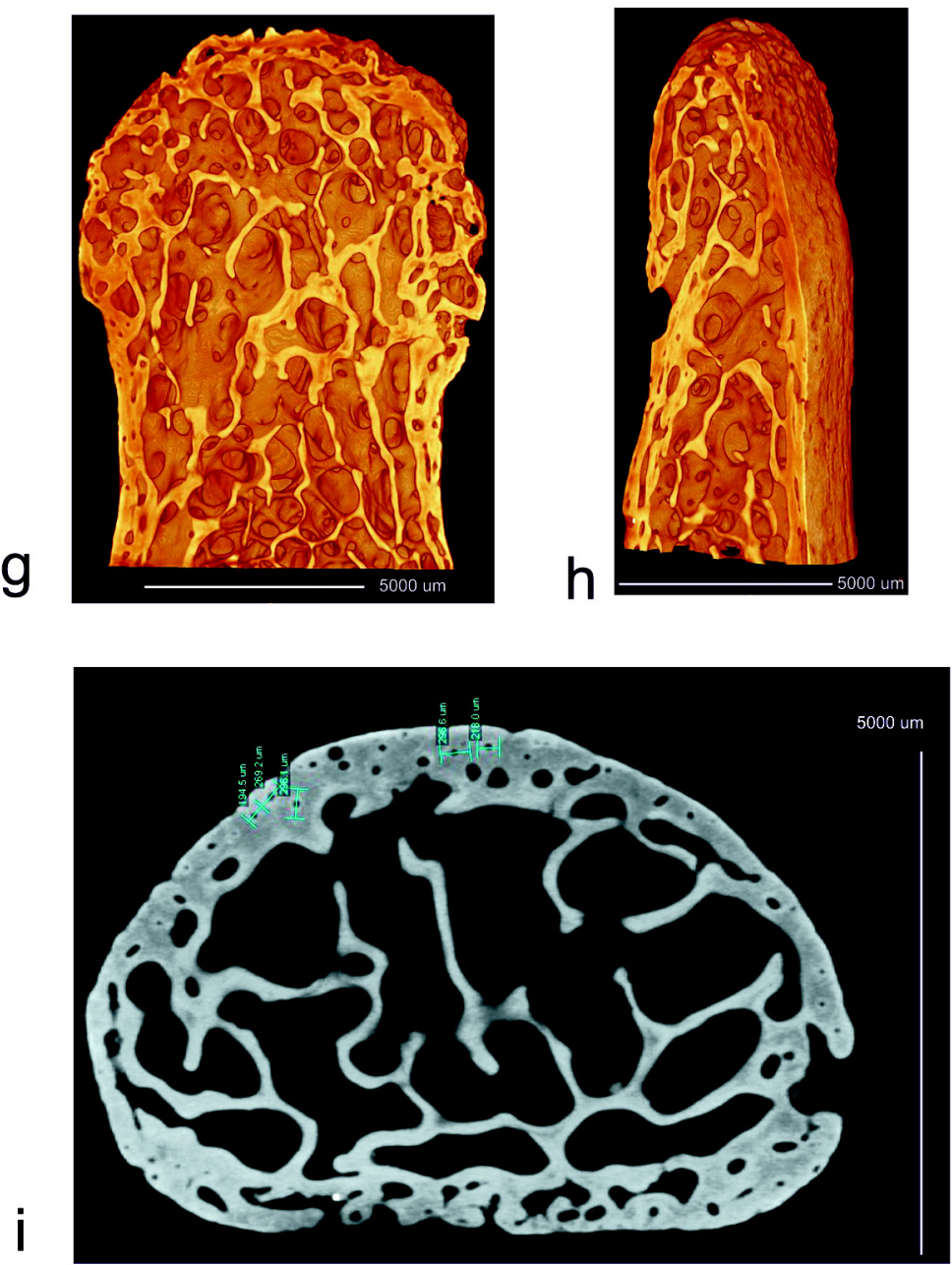

Figure 2. Distal manual phalanx Chagyrskaya 56 (16-2-12). a. dorsal view, b. lateral view, c. palmar view, d. lateral view, e. lateral view by the micro-focus X-ray, f. anterior view by the micro-focus X-ray, g. 3D reconstruction and virtual vertical transverse cross-section in the area of the distal tuberosity, h. virtual vertical anterior-posterior cross-section in the same area, i. virtual cross-section with osteon measurements from the dorsal compact at midshaft (top of the figure)

Рисунок 2. Дистальная фраланга кисти Чагырская 56 (16-2-12). а. дорзальная поверхность, b. вид сбоку, с. ладонная поверхность, d. вид сбоку, е. боковая проекция на микрофокусной рентгенограмме, f. передняя проекция на микрофокусной рентгенограмме, g. Трехмерная реконструкция и вертикальный виртуальный поперечный срез в области дистальной бугристости, h. виртуальный вертикальный сагиттальный срез в той же области.

і. виртуальное сечение с измерениями остеонов дорзальной компакты на уровне середины (верх рисунка) 


\section{$1 \mathrm{~cm}$}

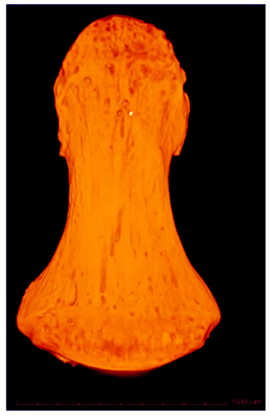

a

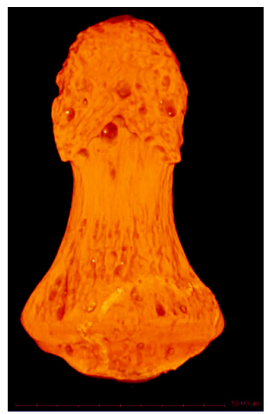

b

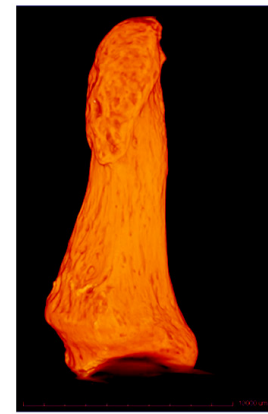

C

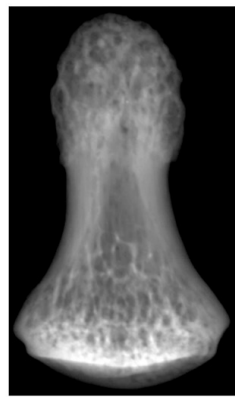

d

e
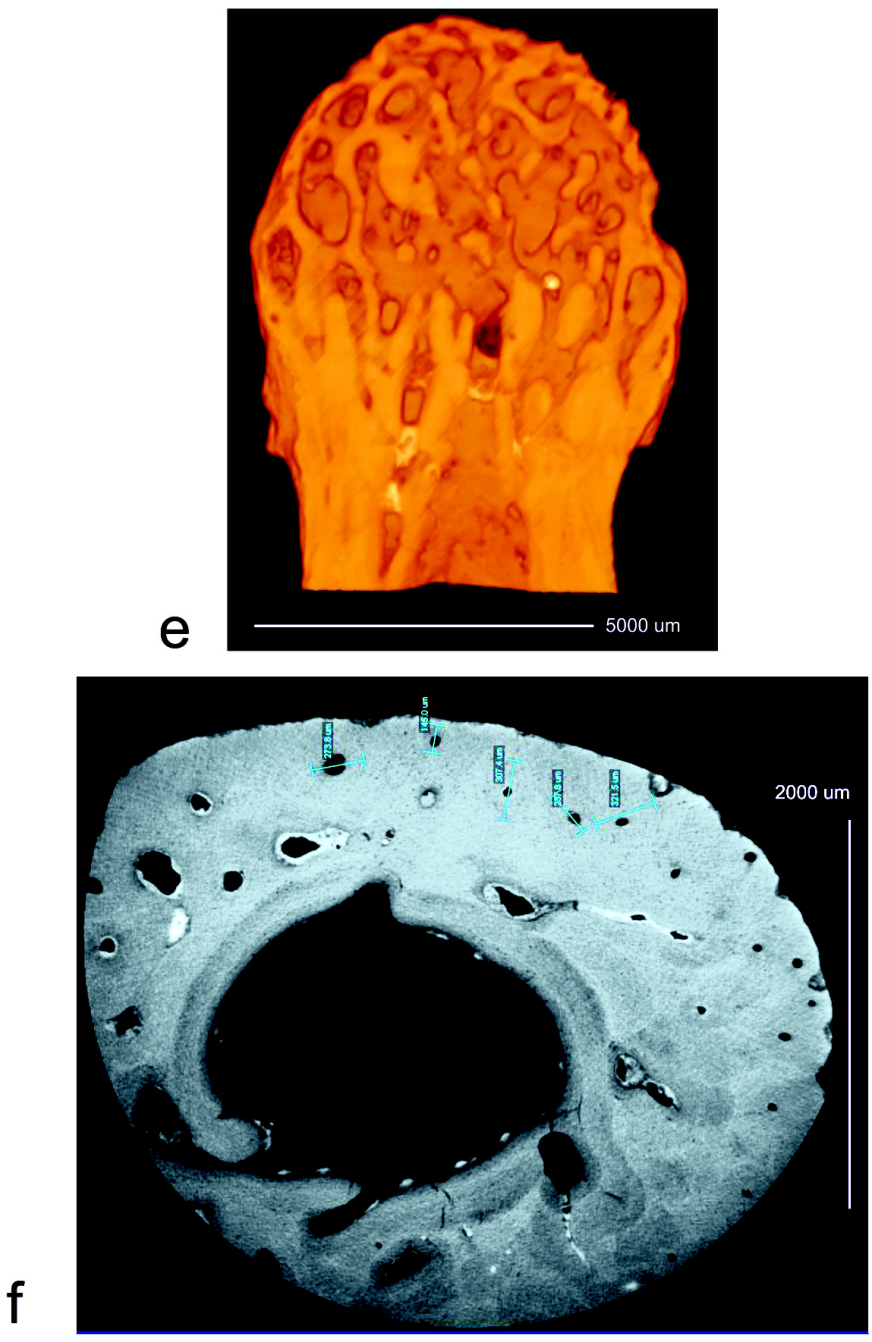

Figure 3. Distal manual phalanx Strashnaya 4. a. dorsal view of the 3D reconstruction based on micro-tomography results, b. palmar view, c. lateral view, d. anterior view by the micro-focus X-ray, e. 3D reconstruction and virtual vertical cross-section in the area of the distal tuberosity, f. virtual cross-section with osteon measurements from the dorsal compact at midshaft (top of the figure)

Рисунок 3. Дистальная фраланга кисти Страшная 4. а. дорзальная поверхность на трехмерной реконструкции по результатам микротомографии, b. ладонная поверхность, с. вид сбоку, d. передняя проекция на микрофокусной рентгенограмме, е. Трехмерная реконструкция и вертикальный виртуальный срез в области дистальной бугристости,

f. виртуальное сечение с измерениями остеонов дорзальной компакты на уровне середины (верх рисунка) 


\section{$1 \mathrm{~cm}$}

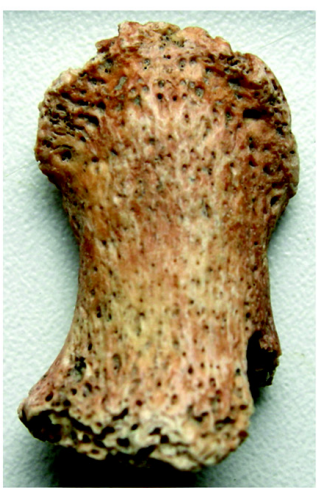

a

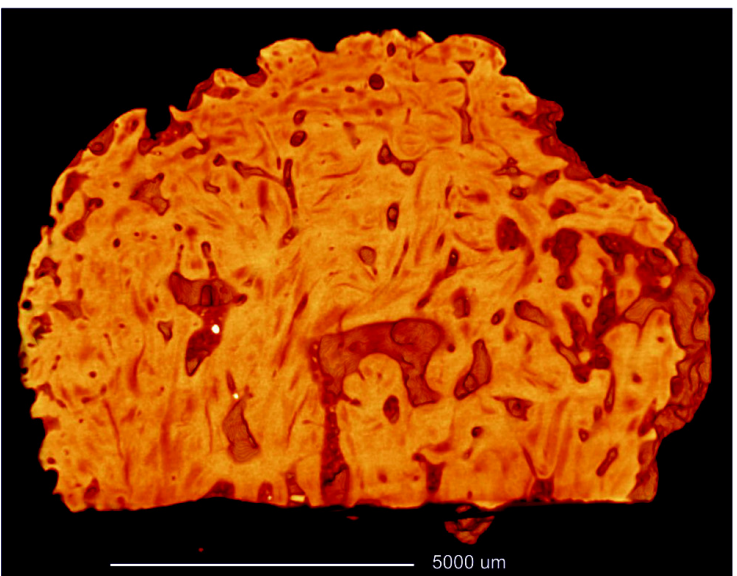

e

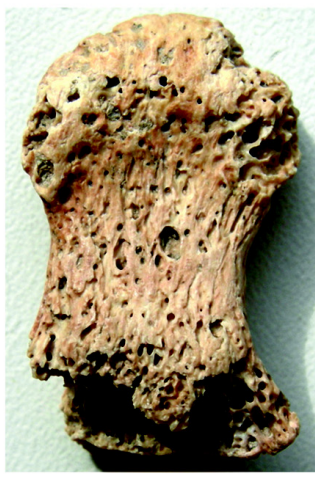

C

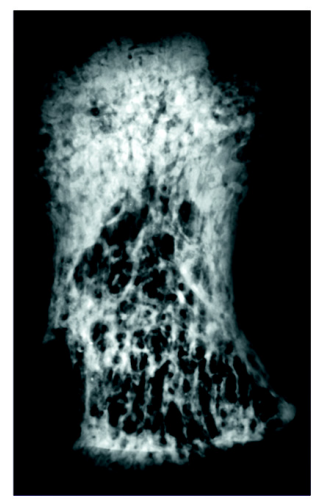

d
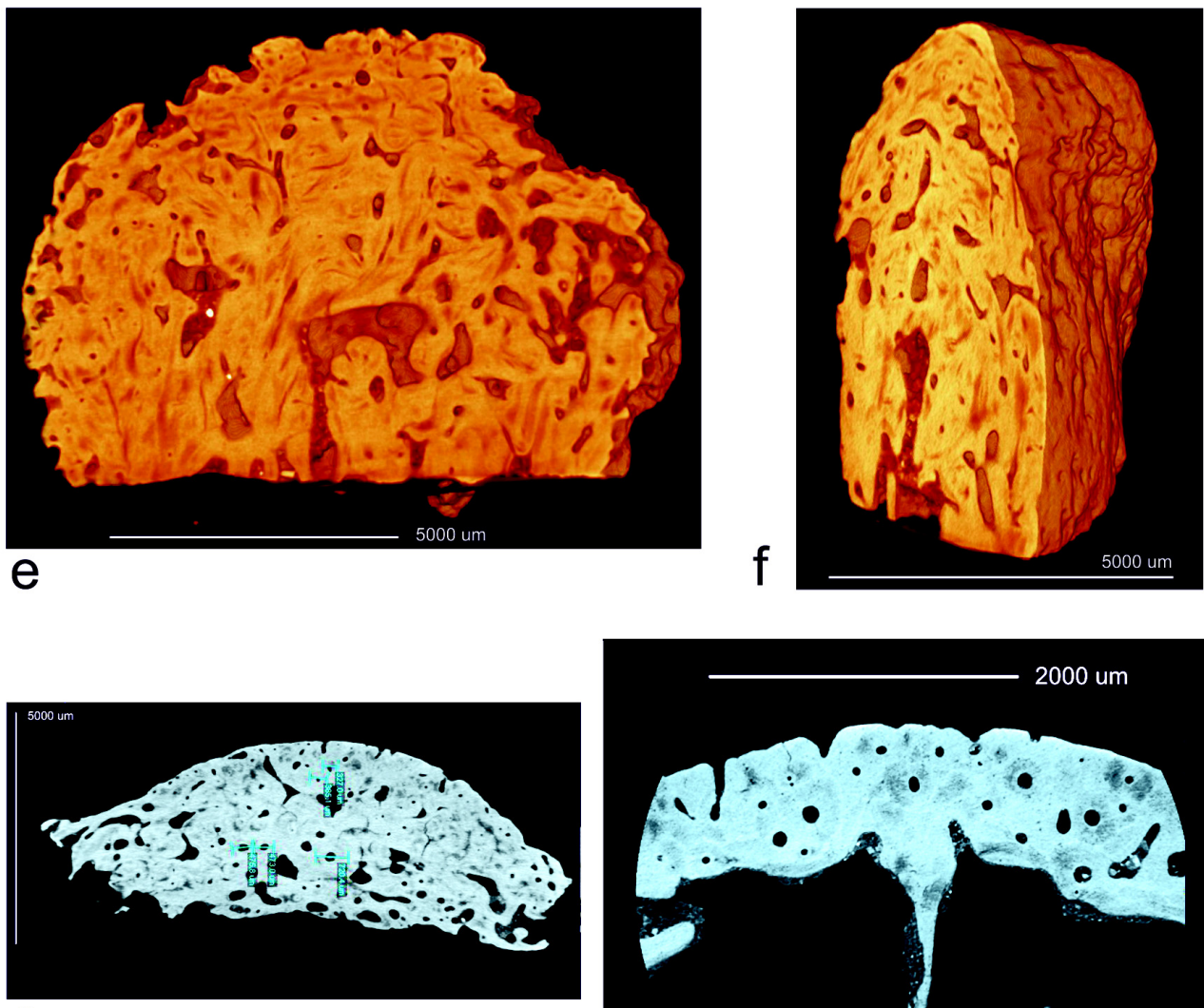

g

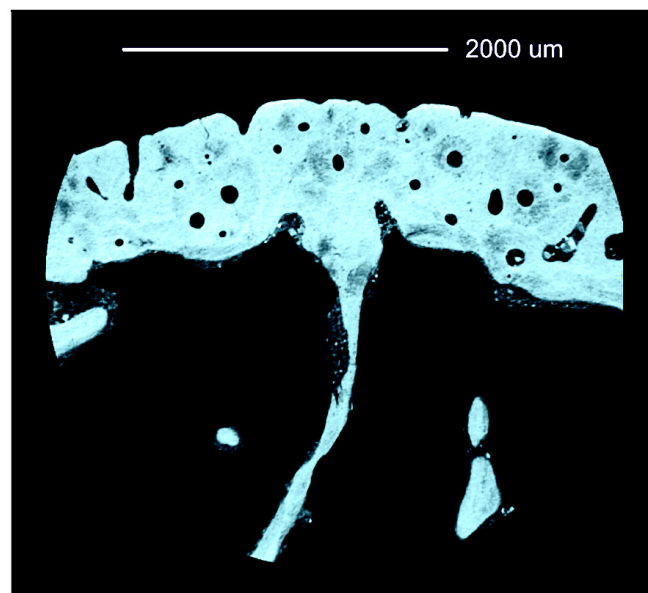

Figure 4. Distal manual phalanx Denisova 9. a. dorsal view, b. lateral view, c. palmar view, d. anterior view by the micro-focus X-ray, e. 3D reconstruction and vertical transverse cross-section in the area of the distal tuberosity,

f. virtual vertical anterior-posterior cross-section in the same area, g. virtual slice at the level of the transition from the distal tuberosity to the diaphysis, h. virtual slice of the dorsal compact at midshaft (top of the figure)

Рисунок 4. Дистальная фаланга кисти Денисова 9. а. дорзальная поверхность, b. вид сбоку, с. ладонная поверхность, d. передняя проекция на микрофокусной рентгенограмме, е. Трехмерная реконструкция

и вертикальный виртуальный срез в области дистальной бугристости, f. виртуальный вертикальный сагиттальный срез в той же области. g. виртуальный срез на уровне перехода от дистальной бугристости к диафизу. h. Виртуальный срез дорзальной компакты на уровне середины (верх рисунка) 


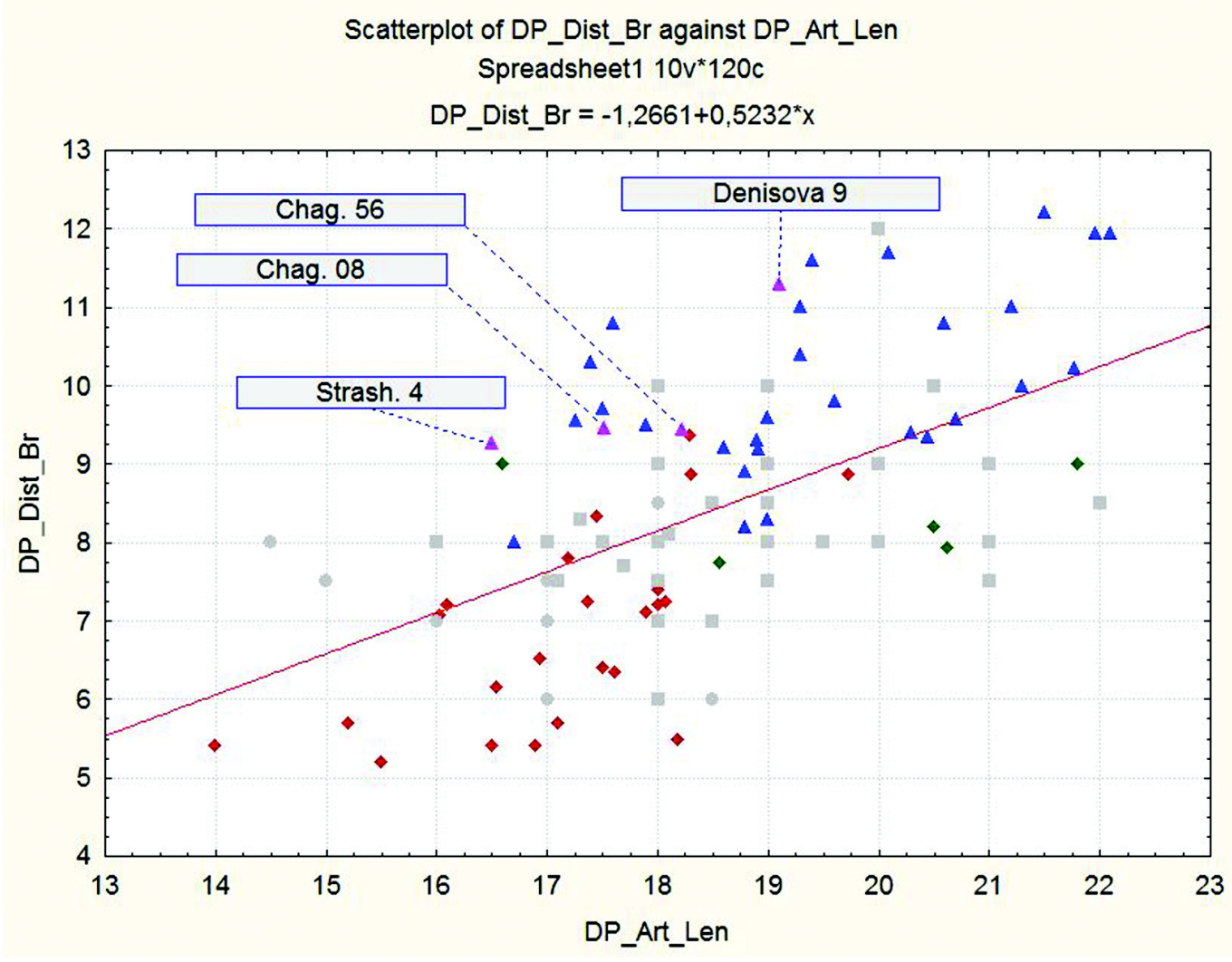

Figure 5. Articular length and distal breadth of distal manual phalanges in the Pleisocene and Holocene hominins. Blue triangles: Neanderthals, red rhombs: early modern humans, grey squares: modern males, grey circles: modern females Рисунок 5. Сочленовная длина и дистальная ширина фраланг кисти у плейстоценовых и голоценовых гоминин. Синие треугольники: неандертальцы, красные ромбы: ранние современные люди, серые квадраты: современные мужчины, серые кружки: современные женщины

\section{Microanatomy}

Denisova 9. The appearance of the distal manual phalanx from Denisova Cave is consistent with a young adult or adult individual.

Micro-focus imaging before DNA sampling [Mednikova, 2013b; Fig. 4d] shows differences between this phalanx and the distal phalanges from Kiik-Koba 1 (Neanderthal) and Sunghir 1 (Upper Palaeolithic $H$. sapiens): it shows a coarser structure of the trabeculae and widespread sclerotisation of the upper portion of the bone shaft, as well as multiple erosions of the distal tuberosity. These preliminary observations were followed up by more detailed studies.

Scanning of the remaining apical tuft of the phalanx shows that the external contour of the tuberosity expresses local manifestations of intensive osteolysis (Fig. 4e). The internal space of the distal tuberosity was formed by strong, extremely robust and dense trabeculae consisting of bone material. Imaging shows the area as completely osteonised (Fig. 4e, f, g). Osteon size at the level of the transition from the distal tuberosity to the diaphysis are large and varies in the range of 236-720 $\mu \mathrm{m}$ (Fig. 4g).
Diameters of Haversian canals in the middle portion of the slice are wide and vary in range 146-213 $\mu \mathrm{m}$.

A slice of the dorsal compact at midshaft level shows a more typical structure (Fig.4h). The width of the dorsal compact here is $715-1090 \mu \mathrm{m}$. The osteon diameters varies from 160,73 till 392,70 $\mu \mathrm{m}$. Diameters of Haversian canals are in range $60-103$ $\mu \mathrm{m}$. Larger and darker osteons are presented, indicating low mineralisation of the dorsal compact of distal phalanx Denisova 9.

Two phalanges from the Chagyrskaya Cave, both belonged to females of the common (adult) biological age. Although Chagyrskaya 08 and 56 have been excavated in different archaeological strata, their external morphology is very similar and they may belong to one person. Besides other reasons, microanatomical investigation could exclude such possibility.

The dorsal compact at the midshaft level of Chagyrskaya 08 is thin: 620-801 $\mu \mathrm{m}$ (Fig.1.e). Diameters of the osteons in Chagyrskaya 08 vary from 150 to $330 \mu \mathrm{m}$, diameters of Haversian canals vary from 34 till $130 \mu \mathrm{m}$. 


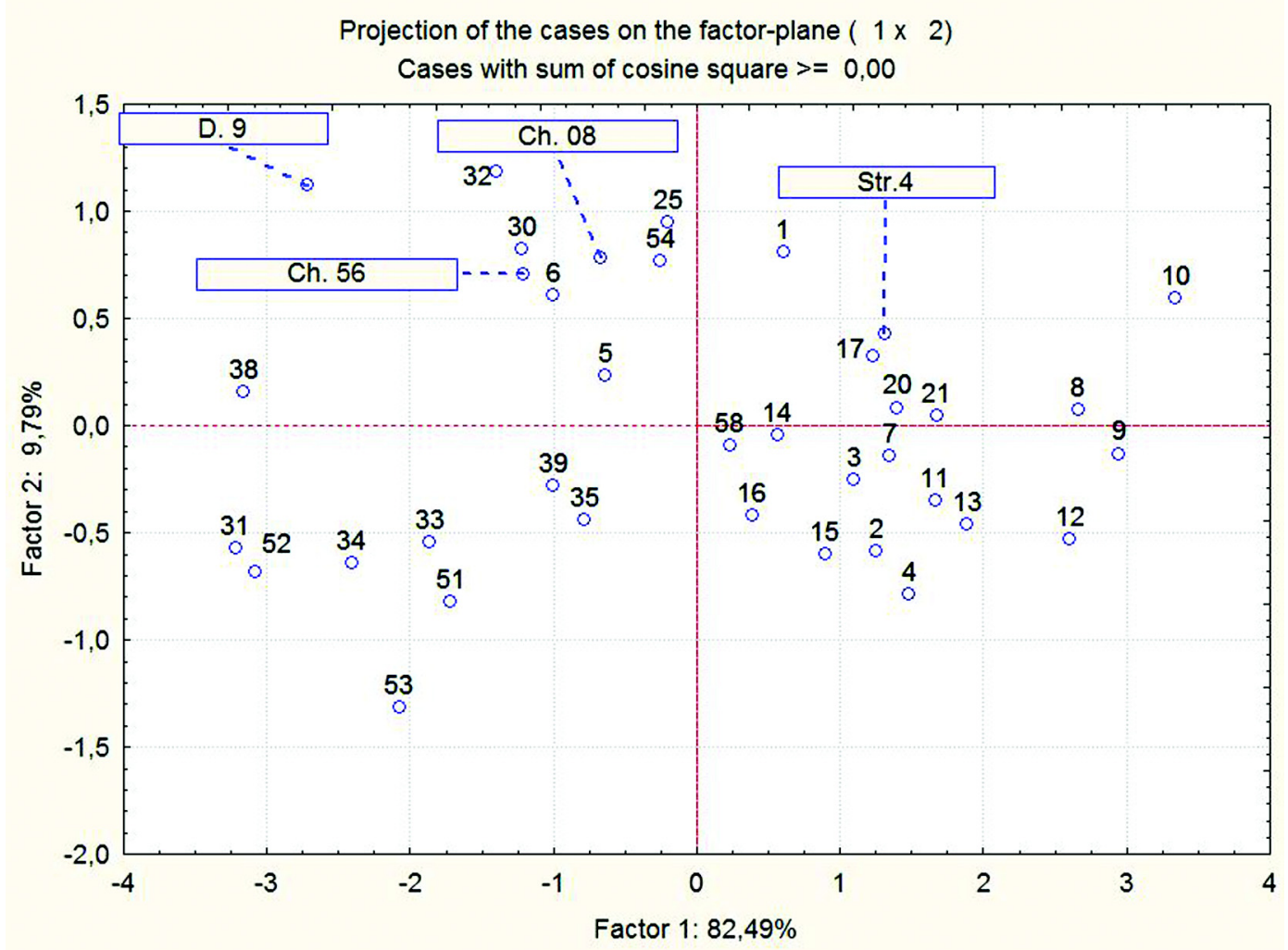

Figure 6. Results of PCA based on 5 morphometric features. Numbers of fossil samples as in the Table 3 Рисунок 6. Результаты применения метода главных компонент по 5 морфометрическим признакам. Номер ископаемых образцов как в таблице 3

Table 4. Comparative data of distal phalanges of the $5^{\text {th }}$ digit in some fossil humans (1,5,6,10 - measurements by M.Mednikova; 8 - measurements by Vilotte et al., 2015;

2,3 - measurements by Trinkaus, 1983; 4 - by Pearson et al., 2008; 9 - by Sladek et al., 2000) Таблица 4. Сравнительные данные по дистальным фалангам 5 луча у некоторых ископаемых людей ( 1, 5, 6,10 - измерения М.Медниковой; 8 - измерения Vilotte et al., 2015; 2,3 - измерения Trinkaus, 1983; 4 - измерения Pearson et al., 2008; 9 - измерения Sladek et al., 2000)

\begin{tabular}{|l|c|c|c|c|c|c|c|c|}
\hline $\begin{array}{c}\text { Distal } \\
\text { phalanges } \\
\text { (side) }\end{array}$ & $\begin{array}{c}\text { Articular } \\
\text { length, } \\
\mathrm{mm}\end{array}$ & $\begin{array}{c}\text { Midshaft } \\
\text { height, } \\
\mathrm{mm}\end{array}$ & $\begin{array}{c}\text { Midshaft } \\
\text { breadth, } \\
\mathrm{mm}\end{array}$ & $\begin{array}{c}\text { Midshaft } \\
\text { circumference, } \\
\mathrm{mm}\end{array}$ & $\begin{array}{c}\text { Proximal } \\
\text { articular } \\
\text { height, } \\
\mathrm{mm}\end{array}$ & $\begin{array}{c}\text { Proximal } \\
\text { articular } \\
\text { breadth, } \\
\mathrm{mm}\end{array}$ & $\begin{array}{c}\text { Distal } \\
\text { height, } \\
\mathrm{mm}\end{array}$ & $\begin{array}{c}\text { Distal } \\
\text { breadth, } \\
\mathrm{mm}\end{array}$ \\
\hline 1.La Ferrassie 1 (left) & 19,33 & 3,78 & 5,29 & 18 & 5,15 & 9,55 & 3,30 & 7,41 \\
\hline 2.Shanidar 3 (?) & 18,1 & 3,8 & 5,3 & 15 & 5,30 & 9,2 & 3,70 & 7,90 \\
\hline 3.Shanidar 4 (?) & - & - & - & - & - & - & 3,6 & 8,5 \\
\hline 4. Omo 1 (?) & 16 & 4 & 3,8 & - & - & 7,5 & - & 5,5 \\
\hline 5.Kostenki 14 (right) & 16,32 & 2,51 & 3,45 & 13 & 5,27 & 8,46 & 2,97 & 5,25 \\
\hline 6.Sunghir 1 (right) & 17,36 & 3,95 & 4,13 & 15 & 5,23 & 7,65 & 3,99 & 6,20 \\
\hline $\begin{array}{l}\text { 7.Abri Pataud 26227 } \\
\text { (right) }\end{array}$ & 15,65 & 3,38 & 3,75 & 12 & 5,70 & 8,39 & 3,00 & 4,70 \\
\hline $\begin{array}{l}\text { 8.Abri Pataud 89-2-465 } \\
\text { (left) }\end{array}$ & - & 3,0 & 3,4 & - & 5,3 & 8,5 & 3,2 & 4,4 \\
\hline 9. DV3 (right) & 14,2 & 2,3 & 3,1 & - & 3,5 & 7,0 & - & 5,5 \\
\hline $\begin{array}{l}\text { 10. Strashnaya 4 } \\
\text { (right) }\end{array}$ & 16,50 & 3,91 & 4,98 & 16 & 5,72 & 8,19 & 3,19 & 6,48 \\
\hline
\end{tabular}




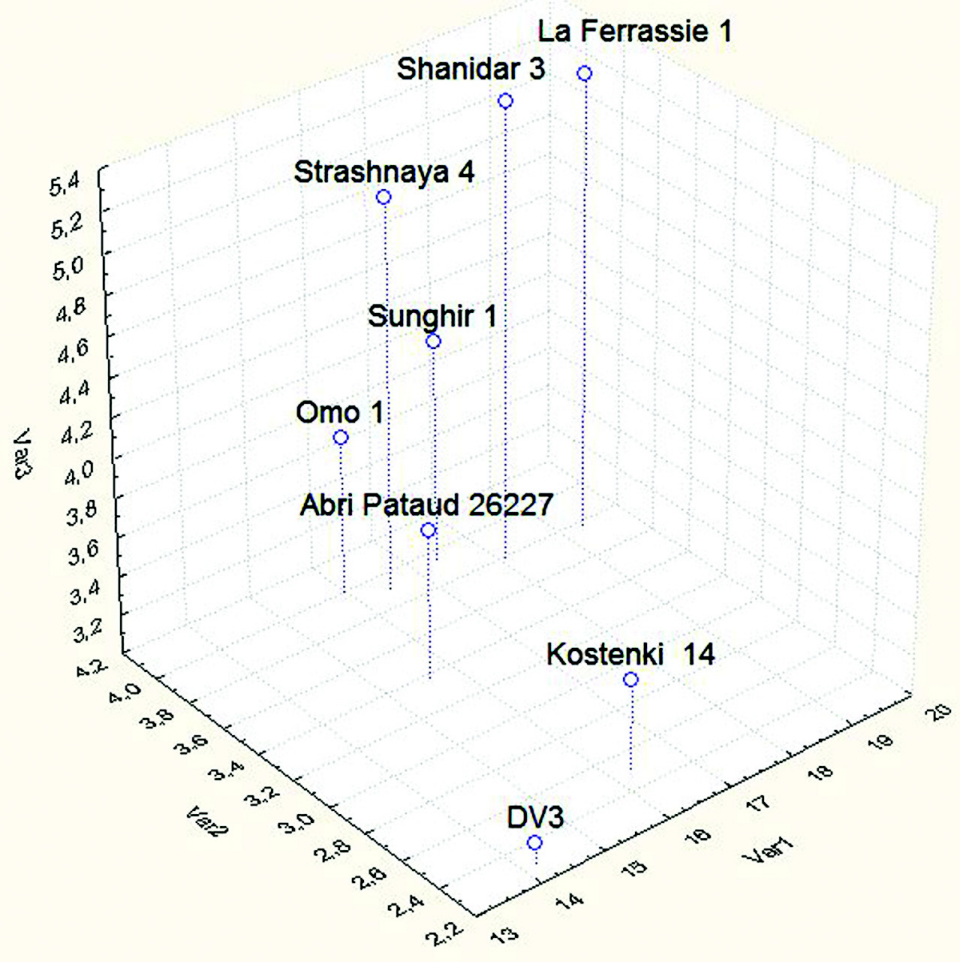

Figure 7. Strashnaya 4 in comparison with distal phalanges of the fifth ray of the Middle and Upper Palaeolithic hominins. Var1 - articular length, Var2 - midshaft height, Var3 - distal breadth

Рисунок 7. Страшная 4 в сравении с дистальными фалангами 5 луча средне- и верхнепалеолитических гоминин. Var1 - сочленовная длина, Var2 - высота в середине диафиза, Var3 - дистальная ширина

The distal phalanx of Chagyrskaya 56 also has small width of dorsal compact at midshaft level (521$889 \mu \mathrm{m})$ (Fig.2i). Diameters of osteons are from 194 to $369 \mu \mathrm{m}$. Diameters of Haversian canal vary as $55-$ $134 \mu \mathrm{m}$.

Both tubular bones show strong evidence of bone remodeling, especially visible in perimedullary space. But Chagyrskaya 08 has numerous resorptive cavities inside the middle portion of the compact. Chagyrskaya 56 seems to have more regular structure of dorsal wall (Fig.1, Fig. 2).

Percent of cortical area (\%CA) also differentiates the samples (58.77 in specimen 08 and 30.88 in 56). That means, in spite of similarity, the phalanges belonged to two different women.

The structure of the bone tissue of phalanges from the Chagyrskaya Cave (Fig. 1 and 2) is markedly different than that of the phalanx Denisova 9. In the Denisova 9 specimen, the phalanx portion nearest the nail is homogeneous and osteonised (Fig. 4). In phalanges Chagyrskaya 08 and 56 (Fig.1 and 2) osteonisation is found only in the peripheral area of the virtual cross-slices, predominantly on the dorsal surfaces next to the nail. The central portions of the shafts are filled with relatively robust but sparse trabeculae consisting of bone material that are not osteonised. The edges of the distal tuberosity are uneven due to small lysed surfaces of presumably pathological origin. The phalanges from the Chagyrskaya Cave show traces of intense blood circulation in the area nearest the fingernail and finger pulp. For example, scanning of Chagyrskaya 08 clearly shows a prominent nutrient foramen, through which a blood vessels and nerves were conveyed (Fig.1).

Even in this diverse context, the phalanx from the Strashnaya Cave is different (Fig.3e, f). The trabeculae form an interior area of the distal tuberosity, as with the samples from the Chagyrskaya Cave. But they are more robust. Thicker and denser shaft walls (dorsal compact 900-1099 $\mu \mathrm{m}$ ) are in common with the compact width of phalanx Denisova 9. But the absence of dark osteons indicates the higher level of mineralisation in comparison with Denisova 9. Osteon dimensions of Strashnaya 4 range from 145 to 321.5 $\mu \mathrm{m}$, diameters of Haversian canals are $32-149 \mu \mathrm{m}$ (Fig. 3f). On the side of the endosteum, the bed of the medullary canal is fringed with a zone of equally sized lamellae approximately $150 \mu \mathrm{m}$ thick. A prominent nutrient foramen is present in the centre of the phalanx, at the level of the edge of the nail plate. 
The phalanges from the Denisova and Strashnaya caves are the thickest-walled and internally most robust, making them similar despite their clear morphological differences: corticalisation measured at mid-shaft (\%CA) is 92.85 and 82.61 respectively. The distal phalanges from the Chagyrskaya Cave are internally gracile and feature a thin layer of compact bone (as mentioned above), the metaphyses and shaft are reinforced by trabeculae, which occupy the space of the medullary canal.

\section{Discussion}

E.Trinkaus [2016] summarised basic trends in hand morphology of Pleistocene representatives of genus Homo, subdivided into early modern humans, Neanderthals, Middle Pleistocene humans (often included within Homo heidelbergensis), Early Pleistocene humans (Homo erectus sensu lato) and Homo naledi. Followed many researchers he pointed out that Neanderthal phalanges have relatively broad epiphyses, involving also the articular facets on the bases of all phalanges. The ratio of proximal maximum breadth and phalangeal length, in general, showed that the Middle and Late Pleistocene archaic humans were relatively robust when compared with the recent humans, whereas the Middle Pleistocene Modern Humans and Upper Palaeolithic Modern Humans were gracile. In the Middle and Late Pleistocene archaic humans had rounded apical tufts. Neanderthals and Middle Pleistocene anatomically modern humans had absolutely broader tufts and relatively longer ulnar distal phalanges than most recent humans. The early modern humans had shorter distal phalanges and narrower tufts.

The early modern and early Upper Palaeolithic humans had apical tufts that were significantly less expanded in comparison with Neanderthals [Mittra et al., 2007].

External measurements and comparative study show that the distal phalanges of the third and second digits of individuals Denisova 9, Chagyrskaya 08 and 56 share Neanderthal morphological features, because they are long, with wide and flat diaphysis and broad, rounded head. Phalanx Strashnaya 4 of the second fifth (?) digit belonged to an individual with patterns of modern anatomy: it was shorter, with high and narrow diaphysis and narrower distal epiphysis.

Thus, our sample under the study consisted from one Neanderthal male (?) Denisova 9, two Neanderthal women Chagyrskaya 08 and 56, and anatomically modern female Strashnaya 4.

While the external dimensions of the distal phalanges from the Chagyrskaya and Denisova caves fall entirely within the range of Neanderthal variability, their internal structures are different. In the distal half of the ungual Neanderthal phalanx from Denisova Cave, the space of the medullary canal was fully displaced by osteonised tissue, and at the level of the midshaft, where the canal is still visible, the walls were massive. By contrast, the phalanges from the Chagyrskaya Cave are thin-walled but the space of the medullary canal along its entire course is filled with non-osteonised trabeculae of bone material, effectively implying the presence of cancellous tissue.

The large inner robusticity of the distal phalanx Strashnaya 4 differs this woman from Neanderthal females Chagyrskaya 08 and 56 . A virtual cross-section of the phalangeal diaphysis shows depositing of lamellar structures of bone material from the side of the medullary canal. This feature joins female Strashnaya 4 with the Upper Palaeolithic man Kostenki 14. But radiography of his distal phalanges revealed complete medullary stenosis [Mednikova, Moiseev, Khartanovich, 2016; Mednikova, 2016a,b], and in case of Strashnaya 4 the medullary canal in the diaphysis is well visible and even free from trabecular involvements met in bones of Altai Neanderthals.

Thickness of the walls of the diaphysis of long bones is usually explained as the result of hypertrophy caused by physical activity, as shown by a range of empirical evidence [Ruff et al., 1993], but it seems unlikely that mechanical stresses could have been so radically different for Neanderthals from two Altai caves, Denisova and Chagyrskaya. We cannot exclude that the inner gracility of phalangeal walls, remarkable in females Chagyrskaya 08 and 56, could be connected with involutive changes. Osteoporosis as a metabolic disease involving loss of bone mineral of advanced age results in decreased bone strength and fractures; today it affects older post-menopausal women, but even in the Medieval age in could imply pre-menopausal bone loss in females after 30 years, caused by number of births and by late weaning of infants [Mays, 2009]. As shown by clinical data, elevated remodeling activity has very rapidly come to be seen as a major cause of osteoporotic fragility [Heaney, 2002].

But thin-walled phalanges Chagyrskaya 08 and 56 seem to be strengthened by cancellous tissue, localised not only in epiphyses, which is true of modern humans, but in diaphyses as well.

Notably, both morphological variants of the internal structure of distal phalanges found in the Altai Neanderthals entailed a reduction in the space occupied by bone marrow. The diaphysis of long bones, including small ones, in healthy anatomically modern adults contains yellow bone marrow (medulla ossium flava), which in turn contains pigmented adipose cells [Kobolak et al., 2015]. Some work has investigated anatomy of the bone marrow in distal manual phalanges.
АНТРОПОЛОГИЯ № 2/2020: 5-25

Anthropology, 2020, no. 2, pp. 5-25
Вестник Московского университета. Серия ХХIII Moscow University Anthropology Bulletin 
It was found early on that small bones of hands and feet contained fatty marrow in the adult, as did also the tibia, fibula, radius, and ulna, whereas the humerus and femur contained a small area of red marrow at the upper epiphysis; the fatty metamorphosis commenced in the most distal parts of the limb bones; the distal bones contain only fatty tissue in their diaphyses, this is the adult condition of the shafts of the long bones; incomplete bony trabeculae are always present in fatty tissue of diaphysis; the fatty change in the epiphyses is complete by the age of 20 years, but small patches of red marrow may remain [Piney, 1922]. Conversion from red to yellow marrow begins in the terminal phalanges of feet and probably the hands just before birth, when all marrow is hematopoetic; but fat marrow is quickly converted back to hematopoetic red marrow when the marrow system is stressed or replaced [Krikun, 1985]. Under normal conditions yellow bone marrow does not perform hematopoietic functions, but in case of severe blood loss - which was quite possible, given the Neanderthals' traumatic lifestyle [Berger, Trinkaus, 1995] - the body can convert yellow marrow to red marrow in order to increase blood cell production [Kobolak et al., 2015].

Bone marrow is a metabolically active structure since, as blood comes into contact with bone tissue, the blood is enriched with mineral salts and regulatory factors. Experiments demonstrated a difference in marrow temperature of distal extremities compared to proximal extremities, with intramedullary gradiant of $4^{0}$ to $8^{0} \mathrm{C}$ in the phalanges compared to the warmer proximal long bones, sternum and skull [Kricun, 1985].

The upper part of distal phalanx of Denisova 9 indicates reduced space for filling of the yellow bone marrow. It resembles radiological condition known as the ivory structure of epiphyses in some modern humans [Kuhns et al., 1973; Laan van der, Thijn, 1986; Herman et al., 1986]. Ivory epiphyses in modern humans are defined as normally shaped epiphyses radiologically shown increase of density and the absence of medullary canal, observed in some congenital syndromes and dysplasias like Thiemann disease, tricho-rhinophalangeal syndrome, variants of multiple epiphyseal dysplasia, Seckel syndrome or even in healthy humans [van der Laan, Thijn, 1986]. Ivory phalanges are more typical in people of African ancestry, and the incidence of the feature was higher in the Nigerian children in comparison with black American subadults [Kuhns et al., 1973; Shaw, Bohrer, 1979].

Separate discussion is merited with regard to traces of bone lysis observed in stronger degree on the phalanx Denisova 9. We should point that this external destruction seems not to be dependent on taphonomy of the fossil bone as can be seen in 3D reconstructions of apical tufts. Phalangeal tuft resorption can be a sign of the frostbite injury after long exposure to cold [Crouch and Smith, 1990]. This corresponds to earlier observations from experienced radiologists and clinicist D.G. Rokhlin [1965] who concerned similar changes in the distal phalanges of three toes of the Neanderthal Kiik-Koba 1. Rokhlin pointed that sometimes frostbite causes bone lysis without osteomyelitis, and it can be a case of Denisova 9.

The majority of studies of microstructural patterns of the compact bone tissue in Pleistocene hominins were undertaken for the purpose of biological age estimation [Thompson, Trinkaus, 1981; Trinkaus, Thompson, 1987; Ericksen, 1991; Abbot et al, 1996; Pfeifer, Zehr, 1996; Sawada et., 2004; Ramsay et al., 2005; Streeter et al, 2001; 2010]. These were done using a destructive technique - a problem which can be overcome now by radiological microscopy and by improvement of visualisation techniques. It was estimated that bone remodeling rates for the Pleistocene humans (e.g. Shanidar 2, 3, 4, 5, 6, Tabun 1, Skhul 3, 6 and 7) are similar to the values of the more recent comparative sample [Streeter et al., 2010]. That means, the data of numerous studies considering bone remodeling in modern and archaeological populations can be used for better understanding of patterns of fossil humans in relation to age, gender, dietary deficiencies or physical load [Parfitt, 1994; Raisz, 1999; Pfeifer et al, 2006; Stout, Lueck, 1995; Paine, Brenton, 2006; Cho, Stout, 2011; Goliath et al., 2016].

To resume the overall picture, at the midshaft level Denisova 9 has thick dorsal compact, large and slightly mineralised secondary osteons, the smallest diameters of Haversian canals. Two Neanderthal females from Chagyrskaya show common features: thin compact, smaller osteons, low density of compact tissue, larger Haversian canals. The anatomically modern woman Strashnaya 4 has thick and very dense, highly mineralised compact with dimensions broadly match those in two Neanderthal females of Chagyrskaya and "intermediate" values of Haversian canals.

It is known, that people of African ancestry have bone mass which is greater and denser than Europeans. The higher osteon population density in European-Americans in comparison with AfricanAmericans is supported by observations in South Africa. Europeans show greater cortical porosity and larger osteon size than Africans. The young African Americans have larger cortical area [Cho et al., 2002]. They have lower urinary calcium levels, resembling lower bone resorption than Europeans, they have slower bone turnover rate, greater rate of subperiosteal opposition [Cho et al., 2006].

Altogether, these data for modern humans indicate that the owner of distal phalanx Strashnaya 4 saved patterns of the relatively recent tropical ancestry. A find at Ust-Ishim indicates $H$. sapiens settlement in Western Siberia approximately 45 ka [Fu et al., 2014], and 
Strashnaya 4 increases number of the finds of Pleistocene modern humans in Siberia.

The Neanderthal women in Chagyrskaya probably demonstrate features of cold-adapted morphology and histology, connected with higher level of bone remodeling and with higher vascularisation. In particular, it can be visible in larger nutritive foramens and larger Haversian canals. Notably, discussion about larger apical tufts in Neanderthals with comparison of modern warm- and coldadapted humans gave inconclusive results, since modern Inuits have small pulp [Mittra et al, 2007]. It is possible that the study of thin structures could be also informative in evaluation of metabolic intensity. Morphological data were quite recently confirmed by the study of the highcoverage Neanderthal genome of Chagyrskaya 08 specimen. It is more closely related to Vindija 33.19 and other late Neanderthals in western Eurasia than to the Denisova 5 Neanderthal. Generally speaking, it is related to Neanderthal populations that moved east sometime between 120 and 80 thousand years ago [Mafessoni et al., 2020].

Finally, Denisova 9 has typical (?) Neanderthal features (large osteons, low density and mineralisation of compact bone at the midshaft level), but also very thick walls of the bone, ivory epiphyses and relatively small diameters of Haversian canal. We should remind that this bone was found in the level 12 of Denisova Cave, rather more ancient than the level 11.4 - where the pedal phalanx was found which gave the high quality Neanderthal genome [Prüfer et al., 2014]. Additionally the palaeogenetic study showed that the Altai Neanderthals from Denisova are a group, who had recent contributions of modern humans [Kuhlwilm et al., 2016].

Overall it can be suggested that the Neanderthals in Altai resulted from different waves of migration.

\section{Conclusion}

The isolated distal manual phalanges considered in our study from adult hominid individuals in Pleistocene deposits of Altai caves are not common, but they constitute a valuable source of information for understanding the scale of morphological variability among the population of this area of contact and hybridisation.

During the Pleistocene era, representatives of the lineage of Denisovans, who had long since settled this location, encountered newcomers of Neanderthal origin. Preliminary research indicated Neanderthal appearances in the Okladnikov, Chagyrskaya and Denisova caves. Study of high-coverage genome of a Neanderthal woman from Denisova (stratum 11.4) revealed a hybrid origin of a group with gene flow between Neanderthals, Denisovans and modern humans [Prüfer et al., 2014]. It is shown in later research that Altai Neanderthals from Denisova were the only Neanderthal group with separate ancestry, dating from around 100000 years ago or more, which appeared from modern humans who had diverged early in Africa [Kuhlwilm et al., 2016].

Describing the features of the macro- and microanatomy of four adult distal manual phalanges from excavations in the Chagyrskaya, Denisova and Strashnaya caves, we tested a hypothesis that the Pleistocene Altai Mountains could be the home of humans who belonged to distinctive lineages. We also checked an idea about the high morphological diversity among Neanderthals in Altai in the context of their possible genetic or chronological differences.

According to the data of their macromorphology, three of the studied bones (Denisova 9, Chagyrskaya 08 and 56) seem to be Neanderthal. They are long, with wide and flat diaphysis, with wide and rounded apical tuft. The fourth, a distal phalanx Strashnaya 4 belonged to a representative of modern humans: it was short, with high and narrow diaphysis, and narrower in comparison with Neanderthals apical tuft.

Based on data obtained by non-destructive radiological investigation, we can conclude that bones studied differ strongly according to their inner robusticity. Because of thick walls the Neanderthal phalanx Denisova 9 is much closer to the "modern" specimen Strashnaya 4, than to the phalanges of other Neanderthals from the Chagyrskaya Cave.

Denisova 9 presents a picture typical for so called ivory epiphyses - with osteonisation of the head and with distal half of the shaft with complete displacement of medullary space. Two Neanderthals from Chagyrskaya seem to be different. Their thin-walled phalanges are filled throughout by cancellous bone tissue. In the thickwalled phalanx Strashnaya 4 medullary space of the diaphysis is visible well.

In the middle portion of the dorsal compact at the midshaft level, Denisova 9 has large and low mineralised secondary osteons with relatively narrow Haversian canals. Both these Neanderthals from Chagyrskaya show smaller osteons, low density of compact tissue, larger Haversian canals. Strashnaya 4 has thick and very dense, highly mineralised compact with diameters osteons broadly matching those in the two Neanderthals of Chagyrskaya but with narrower Haversian canals.

Our data might support the attribution of the Neanderthals Denisova 9 and Chagyrskaya 08 and 56 to two different groups. The appearance of the anatomically modern Strashnaya 4 shows that during Pleistocene the environment of the Altai Mountains attracted humans of different lineages.
АНТРОПОЛОГИЯ № 2/2020: 5-25

Anthropology, 2020, no. 2, pp. 5-25
Вестник Московского университета. Серия ХХIII Moscow University Anthropology Bulletin 


\section{Acknowledgements}

Author is grateful to Dr. A.P. Derevyanko, Dr. M.V. Shunkov, Dr. S.V. Markin, Dr. A.I. Krivoshapkin (Institute of Archaeology and Ethnography of the Siberian Branch RAS) for opportunity to study Siberian fossils; to "Systems for Microscopy and Analysis", Moscow and more particularly to Mr. Victor Zagvozdin for technical support; to Museum of Natural History in Paris and especially to Dr. A. Froment, Ph. Mennecier, V. Laborde, and Dr. V. Khartanovich (Kunstkamera RAS, SanktPetersbourg), who granted access to comparative material. Study was provided as a part of government assignment, topic № AAAA-A18-118011790092-5.

\section{References}

Bonch-Osmolovsky G.A. Kist iskopaemogo cheloveka iz grota KiikKoba. Paleolit Kryma. 2 [Hand of fossil human from Kiik-Koba shelter. (Paleolithic of Crimea. 2)]. Moscow, Leningrad: Izd. AN SSSR, 1941. (In Russ.).

Derevianko A.P., Markin S.V. Mustie Gornogo Altaya (po materialam peshery im. Okladnikova) [Moustier of Altai Mountains (based on data from Okladnikov Cave)]. Novosibirsk: Nauka, 1992. 224 p. (In Russ.). Mednikova M.B. Kist sungirza. Novye dannye o stroenii trubchatykh kostei [Hand of Sunghir 1(new data about built of tubular bones)]. Vestnik Moskovskogo universiteta. Seria XXIII, 2012, 4, pp. 4-17. (In Russ.).

Mednikova M.B., Moiseyev V.G., Khartanovich V.I. Stroenie trubchatykh kostey kisti u obitateley verkhnepaleoliticheskih stoyanok Kostenki 14 I 8 (evoluzionny I bioarckheologicheski aspekty) [Structure of manual tubular bones of inhabitants of Upper Palaeolithic sites Kostenki 14 and 8 (evolutionary and bioarchaeological aspects]. Vestnik Moskovskogo universiteta. Seria XXIII, 2016, 1, pp. 20-34. (In Russ.). Rokhlin D.G. 1965. Bolezni drevnikh lyudey (kosti lyudey raznykh epoch normalnye I patologicheski izmenennye) [Disease of ancient people (bones of people of different ages normal and pathologically changed)]. Moscow, Leningrad: Nauka. 304 p. (In Russ.).

Abbott S., Trinkaus E., Burr D.B. Dynamic bone remodeling in later Pleistocene fossil hominids. Am. J. Phys. Anthropol., 1996, 9, pp. 585-601.

Berger T.D., Trinkaus E. Patterns of Trauma among the Neandertals. J. Archaeol.Science, 1995, 22, pp.841-852.

Brown S., Higham T., Slon V., Рддbо S., Meyer M. et al. Identification of new hominin bone from Denisova Cave, Siberia using collagen fingerprinting and mitochondrial DNA analysis. Scientific Reports, 2016. 6 (23559), pp. 1-8. DOI: 10.1038/srep23559.

Buzhilova A.P. Dental remains from the Middle Paleolithic layers of Altai cave sites. Archaeology, Ethnography and Anthropology of Eurasia, 2016, 41 (1), pp. 55-65.

Christensen A.M. Techniques for siding manual phalanges. Forensic Science International., 2009, 193, pp. 84-87.

Crescimanno A., Stout M.S. and S.D. Differentiating fragmented human and nonhuman long bone using osteon circularity. J. Forensic Sci., 2009, 57 (2), pp. 287-294.

Cho H., Stout S.D., Madsen R.W., Streeter M.A. Population-specific histological age-estimating method: a model for known AfricanAmerican and European-American skeletal remains. J. Forensic Sci., 2002, 47, pp. 12-18.

Cho H., Stout S.D., Bishop T.A. Cortical Bone Remodelong Rates in a Sample of African American and European American Descent Groups from the American Midwest: Comparisons of Age and Sex in Ribs. Am. J. Phys. Anthropol., 2006, 130, pp. 214-226.
Cho H., Stout S.D. Age-associated bone loss and intraskeletal variability in the Imperial Romans. J. Anthrop. Sci., 2011, 89, pp.109-125.

Crescimanno A., Stout S.D. Differentiated fragmented human and nohuman long bone using osteon circularity. J. Forensic Sci., 2012, 57, pp.287-294.

Crouch C., Smith W.L. Long term sequlae of frostbite. Pediatric Radiology, 1990, 20, pp. 365-366.

Derevianko A.P., Markin S.V., Shunkov M.V. The Sibiryachikha Facies of the Middle Paleolithic of the Altai. Archaeology, Ethnography and Anthropology of Eurasia, 2013, 41, pp. 89-103. Douka K., Slon V., Jacobs Z., Bronk Ramsey K., Shunkov V.V. et al. Age estimates for hominin fossils and the onset of the Upper Palaeolithic at Denisova Cave. Nature, 2019, 565, pp. 644. DOI:/ 10.1038/s41586-018-0870-z.

Ericksen M.F. Histological estimation of age at death using the anterior cortex of the femur. Am. J. Phys. Anthropol., 1991. 84, pp. 171-179.

Frost H.M. Secondary osteon populations: An algorithm for determining mean bone tissue age. Yearbook Phys. Anthropol., 1987, 30, pp. 221-238.

Fu Q., Li H., Moorjani P., Jay F., Slepchenko S.M. et al. Genome sequence of a 45,000-year-old modern human from Western Siberia. Nature, 2014, 514, pp. 445-450.

Goliath J.R., Stewart M.C., Stout S.D. Variation in osteon histomorphometrics and their impact on age-at death estimation in older individuals. Forensic Science International, 2016, 262, 282e1282e6.

Heaney R. Remodeling and skeletal fragility. Osteoporos. Int., 2002, 14 (Suppl 5), pp. 12-15. DOI 10.1007/s00198-003-1466-4 Herman T.E., Crowford J.D., Cleveland R.H., Kushner D.C. Hand radiographs in Russel-Silver syndrome. Pediatrics, 1986, 79, pp. 743-745.

Jacobs Z., Li B., Derevianko A., Shunkov M., Markin M. et al. Luminescence chronologies for Denisova and Chagyrskaya Caves, southern Siberia, Russia. Proceedings of the European Society for the study of Human Evolution, 2016, 5, Madrid, Museo Arqueolygico Regional, p.128.

Iwaniec U., Grenshaw T.D., Schoeninger M.G., Stout S.D., Ericksen M.F. Methods for improving the efficiency of estimating total osteon density in the human anterior mid-diaphyseal femur. Am. J. Phys. Anthropol., 1998, 107, pp. 13-24.

Karasik D., Arensburg B., Tillier A.-M., Pavlovsky O.M. Skeletal Age Assessment of Fossil Hominids. J.Archaeol., Science, 1998, 25, pp. 689-696.

Kerley E.R. The microscopic determination of age in human bone. Am. J. Phys. Anthropol., 1965, 23, pp.149-164.

Kobolak J., Dinnies A., Memic A., Khademhosseini A., Modasheri A. Mesenchymal stem cells; identification, phenotypic characterization, biological properties and potential regenerative medicine through biomaterial micro engineering of their niche. Methods, 2015. DOI: http//dx.doi.org/10.1016/j.ymeth.2015.09.016.

Krause J., Orlando L., Serre D., Viola B., Prbfer K. et al. Neanderthals in central Asia and Siberia. Nature, 2007, 449, pp. 902-904.

Krause J., Fu Q., Good J.M., Viola B., Shunkov M.V. et al. The complete mitochondrial DNA genome of an unknown hominine from southern Siberia. Nature, 2010, 464, pp. 894-897.

Krikun M.E. Red-yellow marrow conversion: its effect on the location of some solitary bone lesions. Skeletal Radiology, 1985, 14, pp.10-19.

Kuhlwilm M., Gronau I., Hubisz M.J., de Filippo C., Prado-Martinez $\mathrm{J}$. et al. Ancient gene flow from early modern humans into Eastern Neanderthals. Nature, 2016, 530, pp.429-433.

Kuhns L.R., Poznanski A.K., Harper H.A.S., Garn S.M. Ivory epiphyses in the hands. Pediatric Radiology, 1973, 109, pp. 643-648.

Laan van der J.G., Thijn C.J.P. Ivory and dense epiphyses of hand: Thimann disease in three sisters. Skeletal Radiology, 1986, 15, pp.117-122.

Mafessoni F., Grote S., de Filippo C., Slon V., Kolobova K. et al. A high-coverage Neandertal genome from Chagyrskaya Cave. bioRxiv preprint, 2020. DOI: https://doi.org/10.1101/2020.03.12.988956. 
Martiniakova M., Grosskopf B., Omelka R., Dammers K. Vondrakova M. Histological study of compact bone tissue in some mammals: a method of species determination. Internat. J. Osteoarchaeology, 2007, 7, pp. 82-90.

Mays S. The Archaeology of Human Bones. $2^{\text {nd }}$ edition. Routledge, New York, 2009. 424 p.

McCown T.D., Keith A. The Stone Age of the Mount Carmel. The fossil human remains from the Levalloiso-Mousterian. II.: Oxford: Clarendon Press, 1939. $390 \mathrm{p}$.

Mednikova M.B. Postcranial morphology and taxonomy of genus Homo representatives from Okladnikov Cave in Altai. Novosibirsk: IAET SO RAN, 2011a. 127 p.

Mednikova M.B. A Proximal Pedal Phalanx of a Paleolithic Hominin from Denisova Cave, Altai. Archaeology, Ethnography and Anthropology of Eurasia, 2011b, 39, pp.129-138.

Mednikova M.B. An archaic human ulna from Chagyrskaya cave, Altai: morphology and taxonomy. Archaeology, Ethnography and Anthropology of Eurasia, 2013a. 41, pp.66-77.

Mednikova M.B. Distal phalanx of the hand of Homo from Denisova cave stratum 12: a tentative description. Archaeology, Ethnography and Anthropology of Eurasia, 2013b, 4, pp. 146-155.

Mednikova M. Altai Neanderthals and their morphological diversity. Proceedings of the European Society of Human Evolution, 2015, 4, p. 159.

Mednikova M. Evolutionary history of osteosclerosis: a case study of the earliest CroMagnon from the Eastern Europe. Proceedings of the $21^{\text {st }}$ European Meeting of the Paleopathology Association. Moscow, August 15-19, 2016, p.74.

Mednikova M. Who was robuster? A comparative study of smal tubular bone inner robusticity in Neanderthals and the $\mathrm{AMH}$ of the Upper Palaeolithic. Proceedings of the European Society for the study of Human Evolution, 2016b, 5, p.162.

Mednikova M.B., Dobrovolskaya M.V., Viola B., Lavrenyuk A.V., Kazansky P.R. et al. A Micro Computerized Tomography (X-Ray Microscopy) of the Hand Phalanx of the Denisova Girl. Archaeology, Ethnography and Anthropology of Eurasia, 2013, 41, pp. 120-125. Meyer M., Kircher M., Gansauge M.-T., Li H., Racimo F. et al. A high-coverage genome sequence from an archaic Denisovan individual. Science, 2012, 337 (6098), pp. 1028-1029.

Mittra E.S., Smith H.F., Lemelin P., Jungers W.L. Comparative morphometrics of the Primate Apical Tuft. Am.J. Phys. Anthropol., 2007, 134, pp. 449-459.

Mulhern D.M. Rib Remodeling Dynamics in a Skeletal Population From Kulubnarti, Nubia. Am. J. Phys. Anthropol., 2000, 111, pp.519-530

Musgrave J .H. The Neandertals from Krapina, northern Yugoslavia: An inventory of the hand bones. Zeitschrift fbr Morphologie und Anthropologie, 1977, 68 (2), pp.150-171.

Qui S., Fyhrie D.P., Palnitkar S., Rao S.D. Histomorphometric assessment of haversian canal and osteocyte lacunae in differentsized osteons in human rib. Anat. Rec. A Discov. Mol. Cell. Evol. Biol., 2003, 272A, pp. 520-525.

Paine R.R., Brenton B.P. Dietary health does affect histological age assessment: an evoluation of the Stout and Paine (1992) Age estimation equiation using secondary osteons from the rib. $J$. Forensic Sci., 2006, 51, pp. 489-491.

Parfitt A.M. Osteonal and hemi-osteonal remodeling: the spatia and temporal framework for signal traffic in adult human bone. $J$. Cellular Biochemistry, 1994, 55, pp. 273-286.

Patel B.A., Maiolino S.A. Morphological Diversity in the Digital Rays of Primate Hands Kivell, T.L., Lemelin, P., Richmond B.G., Schmitt D. (Eds.). The Evolution of the Primate Hand. Anatomical, Developmental, Functional, and Paleontological Evidence. New York: Springer Science+Business Media, 2016, pp. 55-100.

Pfeifer S., Zehr M.K. A morphological and histological study of the human humerus from the Border Cave. J.Hum.Evol., 1996, 31, pp. 49-59.

Pearson O.M. Postcranial morphology and the origin of modern humans: Ph. D. thesis. N. Y.: State University of New York at Stony Brook, 1997. 783 p.
Pearson O.M., Royer D.F., Grine F.E., Fleagle J.G. A description of the Omo I postcranial skeleton, including newly discovered fossils. J. Hum. Evol., 2008, 55, pp. 421-437.

Piney A. The Anatomy of the bone marrow: with special reference to the distribution of the red marrow. The British Medical Journal, 1922, 2 (32226), pp. 792-795

Pirock D.J., Ramser J.R., Takahashi H., Villanueva A.R., Frost H.M. Normal histological, tetracycline and dynamic parameters in human, mineralized bone section. Henry Ford Hospital Medical Journal, 1966, 14, pp.195-218.

Prüfer K., Racimo F., Patterson N., Jay F., Sankararaman S. et al. The complete genome sequence of a Neanderthal from the Altai Mountains. Nature, 2014, 505, pp. 43-49.

Radovcic J., Smith F.H., Trinkaus E., Wolpoff M.H. The Krapina hominids. An illustrated catalog of skeletal collection. Chroatian Natural History Museum, Zagreb, 1988. 118 p.

Raisz L.G. Physiology and Pathophysiology of Bone Remodeling. Clinical Chemistry, 1999, 45 (8B), pp.1353-1358.

Ramsay H.L, Weaver D.S., Seidler H. Bone histology in the Le Moustier Neandertal child // The Neandertal Adolescent Le Moustier 1. New Aspects, New Results / H.Ullrich (Ed.). Berliner Beitrage zur Vor - und Fruhgeschichte, N.F., 2005, 12, pp. 282-292.

Reich D., Green R.E., Kircher M., Krause J., Patterson N. et al. Genetic history of an archaic hominine group from Denisova Cave in Siberia. Nature, 2010, 468, pp. 1053-1060.

Reich D., Patterson N., Kircher M., Delfin F., Nandineni M.R. et al. Denisova Admixture and the First Modern Human Dispersals into Southeast Asia and Oceania. The Amer. J. Human Genetics, 2011, 89, pp. 516-528.

Robling A.G., Stout S.D. Morphology of drifting osteon. Cell Tissue Organs, 1999, 164, pp.192-204.

Rogers A.R., Harris N.S., Achenbach A.A. Neanderthal-Denisovan ancestors interbred with a distantly related hominin. Science Advances, 2020, 6, eaay5483. DOI: 10.1126/sciadv.aay5483.

Ruff Ch.B., Trinkaus E., Walker A., Larsen C.S. Postcranial robusticity in Homo. I. Temporal Trends and Mechanical Interpretation. Am. J. Phys. Anthropol., 1993, 91, pp. 21-53.

Sawada J., Kondo O., Nara T., Dodo O., Akazawa T. Bone histomorphology of the Dederiyeh Neanderthal child. Anthropol. Sci., 2004, 112, pp.247-256.

Schaefer M., Black S., Scheuer L. Juvenile osteology. A laboratory and field manual. Amsterdam: Elsevier, 2009. $369 \mathrm{p}$.

Shang H., Trinkaus E. The early modern human from Tianyuan Cave, China. Hewston: Texas A\&M University Press. College Station, 2010. 247 p.

Shaw H.A., Bohrer S.P., The incidence of Cone Epiphyses and Ivory Epiphyses of the Hand in Nigerian Children. Am. J. Phys. Anthropol., 1979, 51, pp. 155-162.

Sladek V., Trinkaus E., Hillson S.V., Holliday T.W. The people of the Pavlovian. Skeletal Catalogue and Osteometrics of the Gravettian Fossil Hominids from Dolni Vestonice and Pavlov. Brno: Gloria Rozice, 2000. 244 p.

Slon V., Mafessoni F., Vernot B., de Filippo C., Grote S. et al. The genome of the offspring of a Neanderthal mother and a Denisovan father. Nature, 2018, 561 (7721), pp. 113-116. DOI.org/10.1038/ s41586-018-0455-x.

Stout S.D., Gehlert S.J. Histomorphological identification of individuals among mixed skeletons. Curr. Anthrop., 1979, 20, pp. 803-805.

Stout S.D., Lueck R. Bone remodelling rates and skeletal maturation in three archaeological skeletal populations. Am. J. Phys. Anthropol, 1995, 98, pp. 161-171.

Stout S.D., Paine R.R. Brief communication: histological age estimation using rib and clavicula. Am.J. Phys. Anthropol., 1992, 87, pp. 111115.

Stout S.D., Stanley S.C. Percent osteonal bone versus osteon counts: the variable of choice for estimating age at death. Am.J. Phys. Anthropol., 1991, 86, pp. 515-519.

Stout S.D., Teitelbaum M.D. Histomorphometric determination of formation rates of archaeological bone. Calcif. Tiss. Res., 1976, 21, pp. 163-169. 
Streeter M., Stout S.D., Trinkaus E., Stringer C.B., Roberts M.B., Parfitt S.A. Histomorphometric age assessment of Boxgrove 1 tibial diaphysis. J. Hum. Evol., 2001, 40, pp. 331-338.

Streeter M., Stout S., Trinkaus E., Burr D. Brief Communication: Bone remodeling Rates in Pleistocene humans are not Slower Than the Rates, Observed in Modern Populations: A reexamination of Abbot et al. (1996). Am.J. Phys. Anthropol., 2010, 141, pp. 315-318.

Tompson D.D., Trinkaus E. Age determination for the Shanidar 3 Neanderthal. Science, 1981, 212, pp.575-577.

Trinkaus E. The Shanidar Neanderthals. Academic Press, New York, 1983. $502 \mathrm{p}$.

Trinkaus E. The Evolution of the Hand in Pleistocene Homo. In: Kivell, T.L., Lemelin, P., Richmond B.G., Schmitt D. (Eds.). The Evolution of the Primate Hand. Anatomical, Developmental, Functional, and Paleontological Evidence. New York: Springer Science+Business Media, 2016, pp. 545-572.

Trinkaus E., Thompson D.D. Femoral diaphyseal histomorphometric age determination for the Shanidar 3, 4, 5 and 6 Neanderthals and Neanderthal longevity. Am.J. Phys. Anthropol., 1987, 72, pp. 123-129.
Uyttershaut H.T. Determination of skeletal age by histological methods. Z. Morph. Anthrop., 1985, 75, pp. 331-340.

Villotte S., Chiotti L., Nespoulet R., Henry-Gambier D. Йtude anthropologique des vestiges humains rŭcemment dйcouverts issus de la couche 2 de l'abri Pataud (Les Eyzies-de-Tayac-Sireuil, Dordogne, France). Bulletins et Mŭmoires de la Sociŭtŭ d anthropologie de Paris, 2015, 27, pp.158-188. DOI 10.1007/s13219015-0128-3.

Viola B.Th., Markin S.V., Buzhilova A.P., Mednikova M.B., Dobrovolskaya M.V., Le Cabec A., Shunkov M.V., Derevianko A.P., Hublin J.-J. New Neanderthal remains from Chagyrskaya Cave (Altai Mountains, Russian Federation). Am.J. Phys. Anthropol., 2012, 147, 54, pp.293-294.

Viola B., Mednikova M., Buzhilova A. Chapter 6. The human remains from Chagyrskaya Cave: An illustrated catalogue and preliminary interpretations. Multidisciplinary Studies of Chagyrskaya Cave $-A$ Middle Paleolithic Site in Altai. Novosibirsk: IAET, 2018, pp. 413-432.

Information about Author

Mednikova Maria B. PhD, D.Sci.; ORCID ID: 0000-0002-1918-2161; medma_pa@mail.ru.

Медникова М.Б.

Институт археологии РАН, 117036, улДм.Ульянова, 19, Москва, Россия

\section{ДИСТАЛЬНЫЕ ФАЛАНГИ КИСТИ ВЕРХНЕПЛЕЙСТОЦЕНОВЫХ НОМО ИЗ АЛТАЙСКИХ ПЕЩЕР}

Введение. В статье представлено сравнительное морфологическое исследование дистальных фраланг кисти второго - пятого лучей у ископаемых обитателей горного Алтая. Согласно предшествующим исследованиям, этот регион предположительно служил контактной зоной неандертальцев и денисовцев.

Цель исследования. Мы рассмотрели гипотезу о присутствии на Алтае эпохи плейстоцена гоминид разного происхождения и, в том числе, о существовании разных морфологических вариантов среди неандертальских обитателей Алтая.

Материал и методы. Дистальные фраланги кисти из раскопок в пещерах Денисова, Чагырская и Страшная были измерены, отрентгенографрированы и отсканированы до того, как из них были взяты пробы для ДНК анализа. Сканирование выполнялось с использованием радиологического микроскопа, разрешение которого позволяет комбинировать традиционные методы радиологии и неразрушающей микроскопии.

Результаты. Наши данные демонстрируют высокую морфологическую изменчивость популяции эпохи верхнего плейстоцена. Три из четырех исследованных фраланг были идентифрицированы как неандертальские (Денисова 9, мужчина (?), Чагырская 08 and 56, женщины) благодаря длинному, широкому и уплощенному диафизу, широкой и закругленной дистальной бугристости. Фаланга Страшная 4 характеризуется анатомически современными особенностями и не относится к неандертальским ни по пропорциям, ни по размерам. Она короткая с относительно узким и высоким диафризом. Современные методы радиологического исследования выявляют два различных морфологических варианта, представленных на Алтае неандертальцами из пещер Денисова и Чагырская. Фаланги существенно различаются по внутренней структуре. В дистальной части Денисова 9 пространство медуллярного канала полностью вытеснено остеонизированной тканью, образуя вариант т.н. зубовидного эпифиза, в частности, распространенного среди современных людей афрриканского происхождения. Денисова 9 сходна с сапиенсом Страшная 4 благодаря высоким 
показателям кортикализации в середине диафиза (\%СА 92,85 и 82,61 соответственно). Фаланги Чагырская 08 и 56 тонкостенные (\%СA 58,77 и 30,88). Недеструктивная радиологическая микроскопия вскрыла дальнейшие различия между образцами: высокую плотность компакты в случае фаланги Страшная 4, низкую минерализацию компакты у всех неандертальцев.

Заключение. Полученные морфологические данные могут отражать присутствие на Алтае неандертальских групп, отличавшихся происхождением и/или по хронологии. Особенности фраланги Денисова 9 могут быть обсуждены в контексте гибридного происхождения индивидуума.

Ключевые слова: палеоантропология; остеометрия; Денисова, Чагырская, Страшная пещеры; неандертальцы; анатомически современные люди; радиология; микроскопия

\section{Библиография}

Бонч-Осмоловский Г.А. Кисть ископаемого человека. Палеолит Крыма. М.-Л.: Изд-во АН СССР, 1941. 170 с.

Деревянко А.П., Маркин С.В. Мустье горного Алтая (по материалам пещеры им.Окладникова). Новосибирск: Наука, 1992. 224 с. Медникова М.Б. Кисть сунгирца. Новые данные о строении трубчатых костей // Вестник Московского университета. Серия XXIII, 2012. №4. C.4-17.

Медникова М.Б., Моисеев В.Г., Хартанович В.И. Строение трубчатых костей кисти у обитателей верхнепалеолитических стоянок Костенки 14 и 8 (эволюционный и биоархеологический аспекты) // Вестник Московского университета. Серия XXIII, 2016. № 1. C. 20-34
Рохлин Д.Г. Болезни древних людей (кости людей разных эпох нормальные и патологически измененные). М.-Л.: Наука. 304 с.

\section{Сведения об авторе}

Медникова Мария Борисовна, д.и.н.,

ORCID ID: 0000-0002-1918-2161; medma_pa@mail.ru.

Поступила в редакцию 27.04.2020 принята к публикации 05.06.2020. 